\title{
Neuronal Expression of Nuclear and Mitochondrial Genes for Cytochrome Oxidase (CO) Subunits Analyzed by in situ Hybridization: Comparison with CO Activity and Protein
}

\author{
Robert F. Hevner and Margaret T. T. Wong-Riley \\ Department of Anatomy and Cellular Biology, Medical College of Wisconsin, Milwaukee, Wisconsin 53226
}

Cytochrome oxidase (CO) is a mitochondrial energy-generating enzyme of the oxidative phosphorylation pathway. In neurons, CO activity varies among different cells and compartments (perikarya, dendrites, axons, and terminals) according to their physiological activity and metabolic requirements. Regulation of enzyme protein levels, rather than enzyme turnover number, largely accounts for local variations in CO activity (Hevner and Wong-Riley, 1989, 1990). In the present study, we examined how CO activity and protein levels are related to mitochondrial DNA (mtDNA) and CO subunit mRNA levels in neurons and neuronal compartments. Mammalian CO comprises 13 subunits (Kadenbach et al., 1983), of which three are encoded in mtDNA and 10 in nuclear genes. We studied one mitochondrial-encoded mRNA [subunit I (COI)], two nuclear-encoded mRNAs (COIV, COVIII), and mtDNA, using in situ hybridization to determine their distributions in monkey hippocampus, cerebellum, and primary visual cortex. We compared their distributions with those of $\mathrm{CO}$ activity and protein, determined by histochemistry and immunohistochemistry, respectively. In all regions, the local content of mtDNA was similar, but not identical, to the activity and amount of CO. Expression of COI mRNA was not proportional to mtDNA abundance or $\mathrm{CO}$ activity and protein, but instead was highest in cell bodies, lower in dendrites, and undetectable in axon terminals. COIV and COVIII mRNAs were detected exclusively in perikarya and proximal dendrites. Thus, the nuclear-encoded subunits of $\mathrm{CO}$ are probably translated mainly in neuronal cell bodies and allocated to other compartments posttranslationally. Regulation of $\mathrm{CO}$ was studied in two monkeys treated by monocular tetrodotoxin (TTX) injection, a procedure that blocks impulses from one eye. In those animals, cortical changes in CO activity were correlated with changes in mtDNA and in COI, COIV, and COVIII mRNA. Our results suggest that neu-

\footnotetext{
Received Sept. 27, 1990; revised Jan. 18, 1991; accepted Feb. 13, 1991.

We thank Drs. L. Weiss-Wunder and M.-F. Chesselet for providing detailed in situ hybridization protocols, Drs. E. A. Schon and G. Attardi for supplying cytochrome oxidase subunit cDNAs and mitochondrial DNA, Drs. V. M. Haughton and C. Nguyen-minh for providing monkey brain tissue, Drs. J. Barbieri, G. Cortina, and W. Cashdollar for instruction and use of their facilities while cloning, W. Kaboord and Dr. S. Liu for assistance in the laboratory, and Dr. L. I. Grossman for helpful discussions. This work was supported by NIH Grants NS18122 and EY05439 to M.W.R. and by the Medical Scientist Training Program at the Medical College of Wisconsin to R.F.H.

Correspondence should be addressed to Dr. Margaret T. T. Wong-Riley, Department of Anatomy and Cellular Biology, Medical College of Wisconsin, 8701 Watertown Plank Road, Milwaukee, WI 53226.

Copyright (C) 1991 Society for Neuroscience $0270-6474 / 91 / 111942-17 \$ 03.00 / 0$
}

ronal $\mathrm{CO}$ is synthesized and assembled mainly in cell bodies and indicate that both nuclear and mitochondrial $\mathrm{CO}$ subunit genes are regulated by neuronal activity.

Neurons that are physiologically active are distinguished metabolically by their rapid rate of substrate utilization and, in the case of chronically active neurons, by their high content of enzymes involved in the generation of metabolic energy (Dietrich et al., 1981, 1982; Wong-Riley, 1989). Cytochrome oxidase (CO; ferrocytochrome $c$ : oxygen oxidoreductase, EC 1.9.3.1), also known as complex IV of the mitochondrial respiratory chain, is one of the energy-generating enzymes that has been strongly linked to neuronal functional activity (reviewed by Wong-Riley, 1989). This enzyme catalyzes the last reaction of oxidative metabolism, the main pathway of energy production in brain (Erecinska and Silver, 1989). Mammalian CO comprises 13 subunits, of which three are encoded in mitochondrial genes and 10 are encoded in nuclear genes (Kadenbach et al., 1983, 1987). Thus, CO biosynthesis involves the coordinated expression of two genomes.

Local differences in $\mathrm{CO}$ activity have been found among different brain regions, cortical laminae, neurons, and neuronal compartments (cell bodies, dendritic segments, axons, and terminals). The local activity of $\mathrm{CO}$ is correlated with the physiological activity of each area, cell, or compartment (Kageyama and Wong-Riley, 1982; Livingstone and Hubel, 1984). Furthermore, changes in the physiological activity of neurons can induce parallel changes in the activity of $\mathrm{CO}$. Regulation of $\mathrm{CO}$ activity by neuronal functional activity has been observed following experimentally induced alterations in physiological activity (Wong-Riley and Welt, 1980; Horton and Hubel, 1981; Wong-Riley and Carroll, 1984; Mawe and Gershon, 1986), during development (Mjaatvedt and Wong-Riley, 1988), and with pathology (Wong-Riley, 1989). Thus, CO is now regarded as a metabolic marker for neuronal functional activity (Wong-Riley, 1989).

The molecular mechanisms linking $\mathrm{CO}$ activity to neuronal functional activity have not yet been fully elucidated. Recently, we investigated whether $\mathrm{CO}$ activity is regulated at the level of enzyme amount or enzyme molecular activity, or both. Using immunohistochemistry, we studied the distribution of $\mathrm{CO}$ protein in mouse and monkey brain and compared it with the distribution of $\mathrm{CO}$ activity, shown histochemically. We found that $\mathrm{CO}$ activity was strongly correlated with $\mathrm{CO}$ amount in normal animals as well as in animals with experimentally altered functional activity (Hevner and Wong-Riley, 1989, 1990). These results indicated that $\mathrm{CO}$ activity in neurons is controlled largely 
or entirely by regulation of the local amount of enzyme protein. These studies also suggested that the mechanisms of CO activity regulation might be similar in neurons as in muscle cells. In muscle, chronic stimulation induced increases in $\mathrm{CO}$ activity that were dependent on mitochondrial protein synthesis (Williams and Harlan, 1987). The increases in CO activity were also associated with increased levels of $\mathrm{mtDNA}$ and $\mathrm{CO}$ subunit mRNAs in the stimulated muscles (Williams, 1986; Williams et al., 1986, 1987; Hood et al., 1989).

In neurons, the mechanisms of $\mathrm{CO}$ biogenesis and regulation may be more complicated than in muscle. Neurons have a more complex structure, and their processes may extend several centimeters or more away from the cell body and nucleus. This poses a problem for $\mathrm{CO}$ biosynthesis, because the mitochondria contain genes for only three $\mathrm{CO}$ subunits, while the other 10 CO subunit genes are in the nuclear DNA; thus, the two genomes can be physically separated by large distances. Metabolically, neurons are nonhomogeneous, and neuronal compartments differ in their CO content, even in the same neuron (Kageyama and Wong-Riley, 1982; Hevner and Wong-Riley, 1989). Is nuclear-encoded subunit mRNA selectively transported to compartments that need $\mathrm{CO}$ due to a high physiological activity? Are mitochondrial-encoded mRNAs expressed in direct proportion to mtDNA content? How are the distributions of mtDNA and $C O$ subunit $m R N A s$ related to each other and to $C O$ activity and protein amount? Are the levels of mtDNA and of $\mathrm{CO}$ subunit mRNAs regulated by functional activity in neurons?

To answer these questions, we used in situ hybridization to localize mtDNA and the mRNAs for CO subunit I (COI; mitochondrial encoded), subunit IV (COIV; nuclear encoded), and subunit VIII (COVIII; nuclear encoded) in brain from normal monkeys and from monkeys treated to induce local changes in $\mathrm{CO}$ activity. The hippocampus and cerebellum were studied, because in these regions (1) $\mathrm{CO}$ activity has been localized at the electron microscopic level (Kageyama and Wong-Riley, 1982; Mjaatvedt and Wong-Riley, 1988) and (2) some neuronal compartments are segregated into areas or laminae identifiable at the light microscopic level. The primary visual cortex was also studied, as a model for the local regulation of $\mathrm{CO}$, using the monocular tetrodotoxin (TTX) paradigm (Wong-Riley and Carroll, 1984; Hevner and Wong-Riley, 1990).

\section{Materials and Methods \\ Animal tissue preparation}

Normal monkey heart and brain tissues were obtained from adult male or female macaques (Macaca fascicularis or $M$. radiata) used in a separate, unrelated study and were provided by Drs. V. M. Haughton and C. Nguyen-minh (Medical College of Wisconsin). Two macaques (adult female $M$. mulatta) were used for the CO regulation studies only and were treated with TTX as described previously (Hevner and WongRiley, 1990) for 3 or $7 \mathrm{~d}$. The animals were then given ketamine (20 $\mathrm{mg} / \mathrm{kg}, \mathrm{i} . \mathrm{m}$.) and atropine $(0.05 \mathrm{mg} / \mathrm{kg}, \mathrm{i} . \mathrm{m}$.$) , then deeply anesthetized$ with $\mathrm{Na}$ pentobarbital $(30 \mathrm{mg} / \mathrm{kg}$, i.v., plus $30 \mathrm{mg} / \mathrm{kg}$, i.p., or $65 \mathrm{mg} /$ $\mathrm{kg}$, i.v.) and decapitated. Tissues were removed immediately, cut into blocks for sectioning or nucleic acid extraction, frozen on dry ice, and stored at $-80^{\circ} \mathrm{C}$ until used. For in situ hybridization, $10-\mu \mathrm{m}$ (hippocampus, cerebellum) or 20- $\mu \mathrm{m}$ (primary visual cortex) sections were cut on a cryostat, thaw mounted on slides coated with gelatin ( 300 bloom, Sigma)/chromium potassium sulfate, and frozen at $-80^{\circ} \mathrm{C}$ until the day of the experiment.

\section{Enzymes and reagents}

Restriction enzymes, ribonuclease A (RNAse), placental RNAse inhibitor, bovine serum albumin, and herring sperm DNA were from Boeh- ringer Mannheim. The transcription kit, oligo-dT cellulose, and RNAse Block II were from Stratagene. Uridine $5^{\prime}-\left[\alpha-{ }^{35} S\right.$-thio]triphosphate $[(\alpha-$ ${ }^{35} \mathrm{~S}$-thio)UTP], $1250 \mathrm{Ci} / \mathrm{mmol}$, was from Amersham. Formamide (molecular biology grade), guanidine isothiocyanate (enzyme grade), and yeast tRNA were from Bethesda Research Labs. Ficoll 400 was purchased from Pharmacia. Diethylpyrocarbonate (DEPC) and other reagents were from Sigma, Aldrich, or Research Organics. Solutions for RNA isolation or in situ hybridization were treated with $0.1 \%$ DEPC to destroy RNAse activity and autoclaved (Sambrook et al., 1989).

\section{Hybridization probes}

$D N A$ clones. The clones used in our experiments are shown in Figure $1 A$. Each DNA was inserted into the multiple cloning site (MCS) of the plasmid vector pBS $(+)$ (Stratagene), which contains phage T3 and T7 promoters flanking the MCS. The clones were the gifts of Drs. E. A. Schon (Columbia University College of Physicians and Surgeons) and G. Attardi (Caltech). Some subcloning was done by us to make optimal plasmids for riboprobe synthesis.

Plasmid pHMt8 contains the 1237-base pair (bp) HindIII/XbaI segment of human mtDNA from positions 6204-7441 (numbering of Anderson et al., 1981). This sequence encodes the C-terminal 413 amino acids (aa; $80 \%$ ) of COI. Like all mammalian mitochondrial genes, it lacks introns (Ojala et al., 1980; Attardi and Schatz, 1988) and is thus equivalent to a cDNA.

Plasmid pCOX4.N contains a 427-bp EcoRI/HindIII cDNA fragment encoding the N-terminal 109 aa $(74 \%)$ of mature human COIV as well as the 22 -aa presequence and 34 bp of 5 -untranslated mRNA (Zeviani et al., 1987). Because the COIV cDNA was originally in a plasmid lacking transcription promotcrs, wc cxcised the full-length cDNA with $E c o$ RI, purified it by agarose gel electrophoresis, extracted it from the gel, and ligated it into the EcoRI site of pBS(+). This plasmid was designated pCOX4.21. To facilitate plasmid linearization and transcription, the DNA between the two HindIII sites [one internal to the cDNA and one in the pBS(+) MCS] was excised, and the plasmid was religated. The resulting plasmid contained single $E c o$ RI and HindIII sites flanking the cDNA fragment and was designated pCOX4.N.

Plasmid pCOX8.C contains a 338-bp HindIII/EcoRI cDNA fragment encoding the C-terminal 35 aa $(80 \%)$ of mature human COVIII as well as $231 \mathrm{bp}$ of $3^{\prime}$-untranslated mRNA, including $7 \mathrm{bp}$ of polyA at the $3^{\prime}$ end. The original full-length clone, pCOX8.21 (Rizzuto et al., 1989), lacked unique restriction sites for linearization, so we excised the DNA between the two HindIII sites [one internal to the cDNA and one in the pBS $(+) \mathrm{MCS}$, religated the plasmid, and designated the new construct pCOX8.C. Although more than two-thirds of the cDNA fragment in pCOX8.C comprises $3^{\prime}$-untranslated mRNA, the base sequence in this region is evolutionarily conserved $(81 \%$ nucleotide identity between rat and human; Rizzuto et al., 1989) and may have contributed to hybridization signals.

Probe synthesis. Plasmids were purified by alkaline lysis of bacteria and centrifugation on a $\mathrm{CsCl}$ gradient using standard procedures (Sambrook et al., 1989). Purified plasmids were linearized by restriction enzyme digestion, aliquotted, frozen at $-20^{\circ} \mathrm{C}$, and used as needed. Transcription reactions were done at $37^{\circ} \mathrm{C}$ with $2 \mu \mathrm{g}$ DNA in $40 \mathrm{~mm}$ Tris (pH, 8.0), $8 \mathrm{mM} \mathrm{MgCl}_{2}, 2 \mathrm{~mm}$ spermidine, $50 \mathrm{mM} \mathrm{NaCl}, 0.5 \mathrm{~mm}$ each of ATP, CTP, and GTP, $10 \mu \mathrm{M}$ cold UTP, $2.5 \mu \mathrm{M}\left(\alpha{ }^{3}{ }^{35}\right.$ S-thio $)$ UTP, $38 \mathrm{~mm}$ dithiothreitol (DTT), $25 \mathrm{U}$ placental RNAse inhibitor (Boehringer) or 0.5 U RNAse Block II (Stratagene), and 10 U RNA polymerase in a total volume of $20 \mu \mathrm{l}$. After reaction for $1 \mathrm{hr}$, an additional $10 \mathrm{U}$ RNA polymerase was added, and the reaction mixture was incubated for $1 \mathrm{hr}$ more. The template was then digested with DNAse I (RNAse free), and transcripts were purified and concentrated by phenol/chloroform extraction and ethanol precipitation. The transcripts were dissolved in $20 \mu \mathrm{l} 20 \mathrm{~mm}$ DTT and stored until used (up to $3 \mathrm{~d}$ ). A typical reaction yielded $250-450 \mathrm{ng}$ RNA with specific activity $\sim 3 \times 10^{8} \mathrm{dpm} /$ $\mu \mathrm{g}$. Analysis by formaldehyde agarose gel electrophoresis showed that the transcripts were mostly uniform and full-length (Fig. 1B).

\section{Blot hybridization}

DNA (Southern) blots. DNA from $M$. fascicularis monkeys was purified by the method of Blin and Stafford (1976) as modified by Sambrook et al. (1989). Total DNA was purified from cerebral cortex (yield, $\sim 0.52$ $\mathrm{mg} \mathrm{DNA} / \mathrm{gm}$ tissue), and mtDNA was purified from isolated brain mitochondria (yield, $\sim 0.57 \mu \mathrm{g}$ DNA/mg mitochondrial protein). The mitochondria were isolated from gray matter by the procedure of Ren- 
A
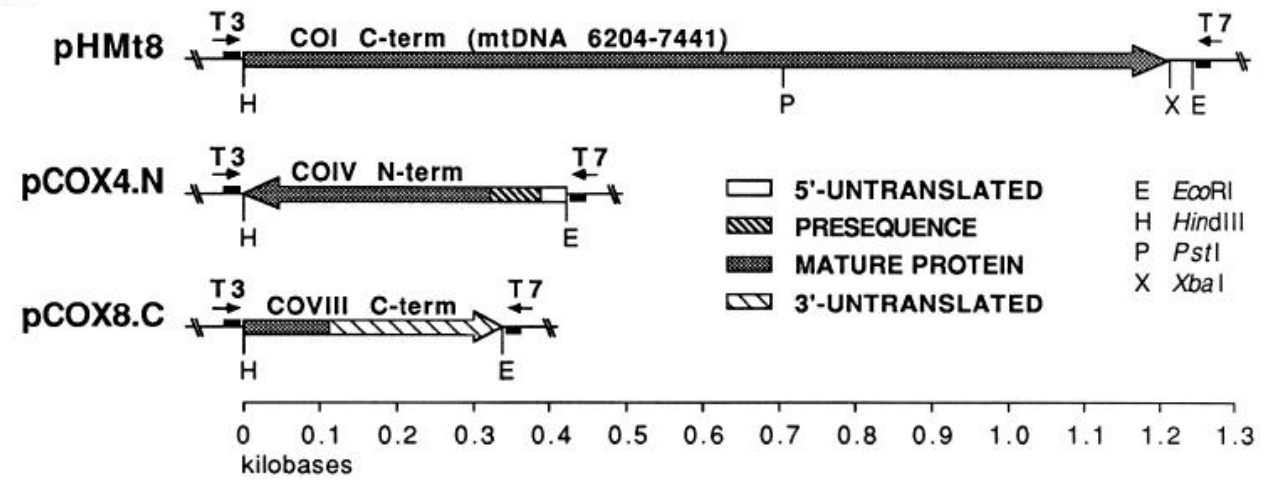

Figure 1. Hybridization probes. A, DNA clones in transcription vector pBS(+) (Stratagene). Plasmid pHMt8 contains human mtDNA encoding the C-terminal $80 \%$ of COI. Plasmids pCOX4.N and pCOX8.C contain human cDNA encoding the $\mathrm{N}$-terminal $74 \%$ of COIV and the C-terminal $80 \%$ of COVIII, respectively, plus some untranslated mRNA. The clones are represented as arrows in the mRNA sense orientation. The coding function of each clone segment is indicated by shading or hatching. The promoters for T3 and T7 RNA polymerase are shown flanking each clone. $B$, Riboprobe size analysis by denaturing gel electrophoresis. Transcripts were purified by phenol extraction and ethanol precipitation, run on $1.5 \%$ agarose gels containing formaldehyde, transferred to nylon membranes (Bio-Rad Zeta-Probe), and detected by film autoradiography. Each riboprobe appears as a major band of the size expected for full-length transcripts. Long exposures revealed the presence of minor bands, but densitometry showed that the major bands always contained more than $90 \%$ of incorporated radiolabel. In this experiment, the COI riboprobes were transcribed from Pst I-cut template DNA; thus, the sense and antisense transcripts differed in size. In most experiments, we used longer $\mathrm{COI}$ probes transcribed from templates cut with EcoRI (sense) or HindIII (antisense). $n t$, nucleotides; $\mathrm{cpm}$, counts per minute.

B

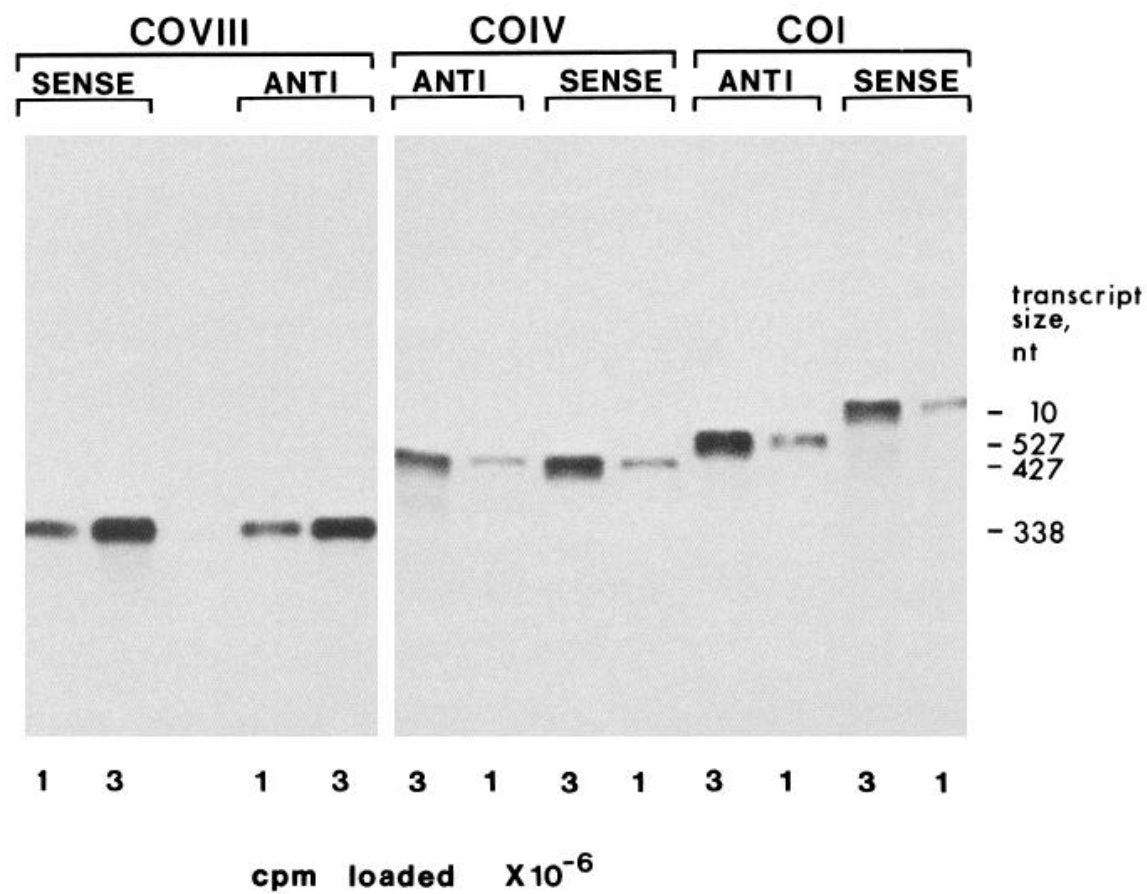

don and Masmoudi (1985) modified as described before (Hevner and Wong-Riley, 1989).

Agarose gel electrophoresis of DNA, capillary transfer to nitrocellulose paper (Immobilon-NC, Millipore), and vacuum drying of blots were done by standard procedures (Sambrook et al., 1989). Prehybridization and hybridization were done in chambers from Hoefer. Blots were prehybridized for $4 \mathrm{hr}$ at $65^{\circ} \mathrm{C}$ in hybridization mix [ $50 \%$ formamide, $5 \times$ standard sodium citrate ( $\mathrm{SSC} ; 1 \times \mathrm{SSC}$ is $150 \mathrm{~mm} \mathrm{NaCl}, 15 \mathrm{mM} \mathrm{Na}_{3}$ citrate; pH, 7), $50 \mathrm{~mm}$ Tris, $2.24 \mathrm{~mm} \mathrm{Na}_{4} \mathrm{P}_{2} \mathrm{O}_{7}, 1 \%$ SDS, $10 \times$ Denhardt's solution $(1 \times$ Denhardt's solution is $0.02 \%$ each of polyvinylpyrrolidone, Ficoll 400, and bovine serum albumin), $5 \mathrm{mM} \mathrm{Na}_{2}$ EDTA, and $150 \mu \mathrm{g} /$ $\mathrm{ml}$ sheared, denatured herring sperm DNA], then hybridized for $18 \mathrm{hr}$ at $48^{\circ} \mathrm{C}$ in hybridization mix containing ${ }^{35} \mathrm{~S}$-labeled riboprobe (COI sense strand synthesized from pHMt 8$)$ at $50-80 \mathrm{ng} / \mathrm{ml}\left(\sim 2 \times 10^{7} \mathrm{dpm} /\right.$ $\mathrm{ml})$. Blots were then washed twice with $2 \times \mathrm{SSC}$ and $0.1 \%$ SDS for 15 min at $55^{\circ} \mathrm{C}$, twice with $0.2 \times \mathrm{SSC}$ and $0.1 \%$ SDS at $55^{\circ} \mathrm{C}$ for $15 \mathrm{~min}$, and twice with $3 \times$ SSC for $15 \mathrm{~min}$ at room temperature. Unhybridized RNA was digested with RNAse A $(10 \mu \mathrm{g} / \mathrm{ml}$ in $3 \times \mathrm{SSC})$ for $30 \mathrm{~min}$ at $37^{\circ} \mathrm{C}$. The blots were further rinsed with $3 \times \mathrm{SSC}$ at room temperature, dried, and exposed to Kodak XAR-5 film.
$R N A$ (Northern) blots. RNA was purified from monkey (M. fascicularis) brain gray matter and from heart by extraction with acid guanidinium thiocyanate-phenol-chloroform (Chomczynski and Sacchi, 1987). RNA yields were $\sim 0.87 \mathrm{mg} / \mathrm{gm}$ brain and $\sim 0.78 \mathrm{mg} / \mathrm{gm}$ heart. Oligo-dT cellulose chromatography (procedure of Sambrook et al., 1989) was used to partially purify polyadenylated RNA. Formaldehyde agarose gel electrophoresis (Sambrook et al., 1989) was used to separate RNA by size. Further RNA blot procedures were exactly as described above for DNA blots, except that probes were antisense strands for each subunit and hybridization and posthybridization washes in $2 \times$ SSC, $0.1 \%$ SDS, and $0.2 \times \mathrm{SSC}, 0.1 \%$ SDS were done at $60^{\circ} \mathrm{C}$ rather than $48^{\circ} \mathrm{C}$ or $55^{\circ} \mathrm{C}$.

\section{In situ hybridization}

Detection of $m R N A$. The procedure of Chesselet et al. (1987) was used with minor modifications. Briefly, unfixed slide-mounted frozen sections were dried and brought to room temperature under a stream of air and fixed for $5 \mathrm{~min}$ in 3\% paraformaldehyde with $0.02 \%$ DEPC. Sections were rinsed with $2 \times$ SSC, acetylated, treated with $0.1 \mathrm{M}$ Tris- 


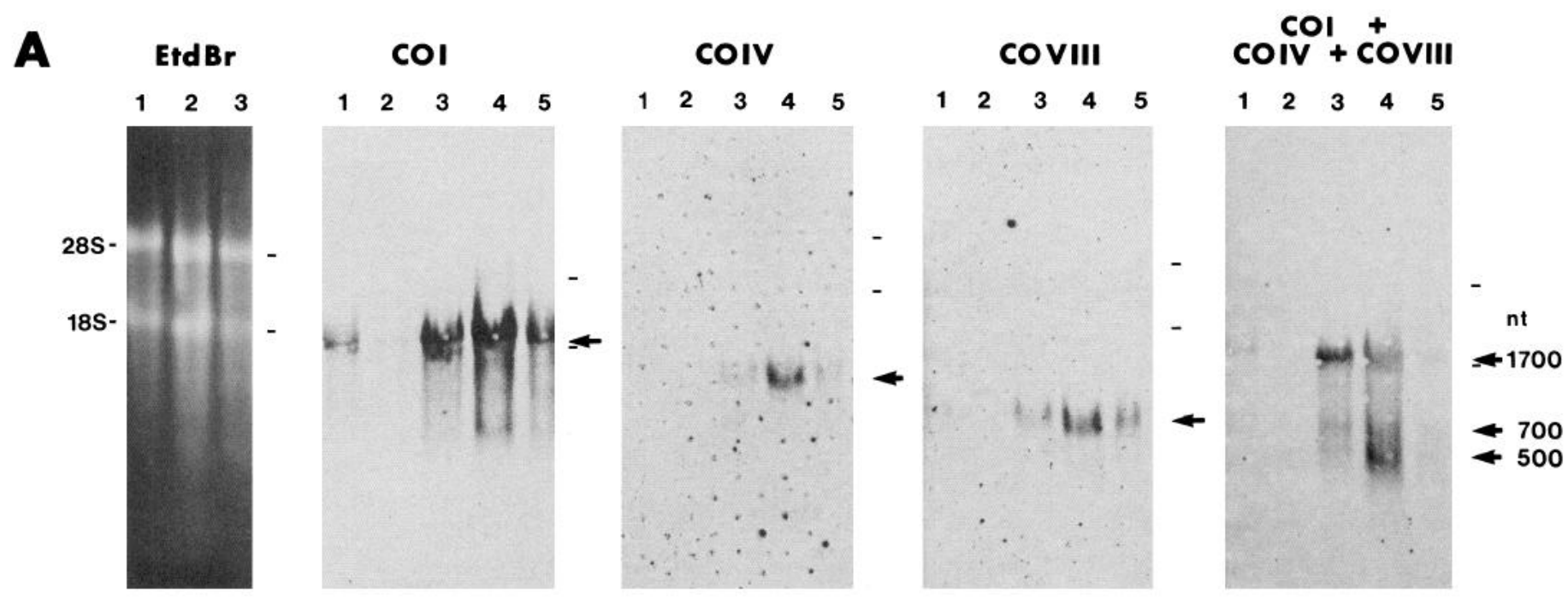

B

EtdBr

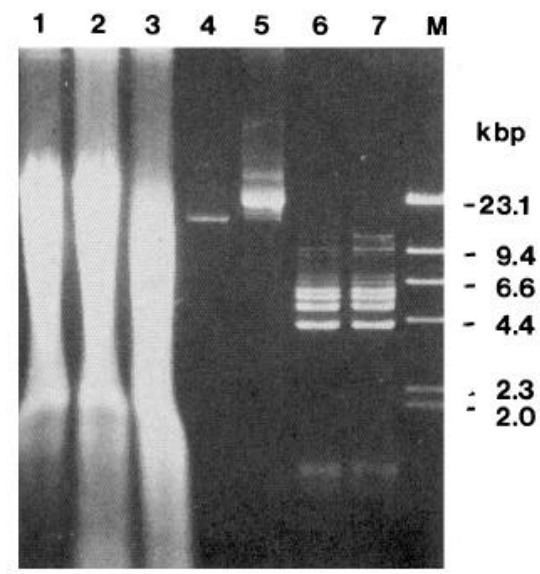

m+DNA

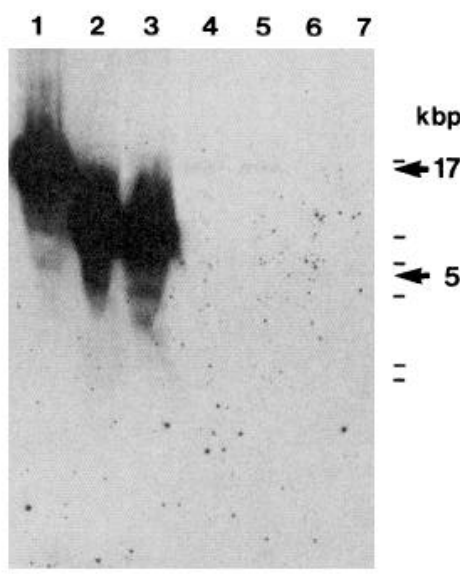

\section{Panel Lane Contents}

A

1
2
3
4
5

brain total RNA
brain A- RNA
brain A+ RNA
heart A + RNA
heart total RNA
total DNA $-E$
total DNA $-H$
total DNA $-E+H$
mtDNA - undig.
mtDNA $-E$
mtDNA $-H$
mtDNA $-E+H$
$\lambda$ DNA $-H$

Figure 2. Human riboprobe hybridization to monkey RNA and DNA. $A$, Northern (RNA) blots. Total, polyadenylated $\left(A^{+}\right)$, and nonpolyadenylated $\left(A^{-}\right)$RNA from monkey heart and brain were run on formaldehyde agarose gels, blotted onto nitrocellulose, and hybridized with ${ }^{35} \mathrm{~S}$-labeled antisense riboprobe for each $\mathrm{CO}$ subunit, as indicated. In each case, the human probe hybridized specifically to the monkey CO subunit mRNA (arrows). An ethidium bromide (EtdBr)-stained gel is shown for comparison. The positions of $18 S$ and $28 S$ rRNA are shown to the right of each blot (dashes). The mRNAs for COI, COIV, and COVIII all were present at higher levels in heart than in brain, were enriched in polyadenylated fractions, and were the same size in both heart and brain. The mRNA sizes given in nucleotides ( $n t)$ are those reported previously for human COI (Ojala et al., 1980), COIV (Zeviani et al., 1987), and COVIII (Rizzuto et al., 1989). The spots on some autoradiograms were artifacts of the hybridization chamber. Lanes contained $20 \mu \mathrm{g}$ total or A $\mathrm{A}^{-}$RNA or $7.5 \mu \mathrm{g} \mathrm{A^{+ }}$ RNA. B, Southern (DNA) blot. Total DNA and purified mtDNA from monkey brain were cut with restriction enzymes or left undigested, run on an agarose gel, denatured, transferred to nitrocellulose, and probed for mtDNA with ${ }^{35} S$-labeled COI sense riboprobe. The enzymes used for cutting were EcoRI $(E)$ and $H$ indIII $(H)$. DNA from phage $\lambda$, cut with $H$, was used as size marker. The major hybridizing band in total DNA had the same size as in authentic mtDNA, that is, 17 kilobase pairs (kbp) for undigested or $E$-digested DNA, and $5 \mathrm{kbp}$ for DNA digested with $H$ or $E+H$. Migration distances differed slightly among lanes due to differences in the amount of DNA loaded. Minor hybridizing bands in total DNA may have represented nuclear pseudogenes or mtDNA degradation products. Because the number of mitochondrial genomes contained in $100 \mathrm{pg}$ mtDNA is twice the number of nuclear genomes contained in $10 \mu \mathrm{g}$ total DNA, an equal signal strength in total DNA and mtDNA lanes would indicate that the total DNA contained two copies mtDNA per nuclear genome. Instead, the signal was far stronger in the total DNA lanes than in the mtDNA lanes, indicating (as expected) that the total DNA contained much more than two copies mtDNA per nuclear genome. Cultured cells contain several hundred copies of mtDNA per nuclear genome (Bogenhagen and Clayton, 1974). For the EtdBr-stained gel, the amount of DNA in each lane was $5 \mu \mathrm{g}$ (lanes 1-3), $160 \mathrm{ng}$ (lane 4), or 240 ng (lanes 5-7 and M). For the blotted gel, the amount of DNA in each lane was $10 \mu \mathrm{g}$ (lanes 1-3) or $100 \mathrm{pg}$ (lanes 4-7).

glycine $(\mathrm{pH}, 7.0)$, dehydrated through graded ethanols, and air dried. Sections were hybridized for $4 \mathrm{hr}$ (COIV, COVIII) or $6 \mathrm{hr}(\mathrm{COI})$ at $50^{\circ} \mathrm{C}$ with $20 \mu$ l hybridization mix (40\% formamide, $8 \%$ dextran sulfate, $4 \times$ SSC, $1 \mathrm{mg} / \mathrm{ml}$ yeast tRNA, $1 \mathrm{mg} / \mathrm{ml}$ herring sperm DNA, $10 \mathrm{~mm}$ DTT, $1 \times$ Denhardt's solution) containing ${ }^{35} \mathrm{~S}$-labeled antisense (sense for controls) riboprobe $(250 \mathrm{ng} / \mathrm{ml})$ under coverslips cut from Parafilm (American Can Company). After hybridization, sections were rinsed with $2 \times$
SSC, then washed for $5 \mathrm{~min}$ and again for $20 \mathrm{~min}$ in $50 \%$ formamide and $2 \times \mathrm{SSC}$ at $52^{\circ} \mathrm{C}$. Unhybridized riboprobe was then digested with RNAse A $(100 \mu \mathrm{g} / \mathrm{ml})$ in $3 \times$ SSC for $30 \mathrm{~min}$ at $37^{\circ} \mathrm{C}$. After a final wash for $5 \mathrm{~min}$ in $50 \%$ formamide and $2 \times \mathrm{SSC}$ at $52^{\circ} \mathrm{C}$, sections were rinsed overnight in $2 \times$ SSC and $0.05 \%$ Triton X-100. Finally, sections were dehydrated through graded ethanols, delipidated in xylene, air dried, and used for film, then emulsion autoradiography. 

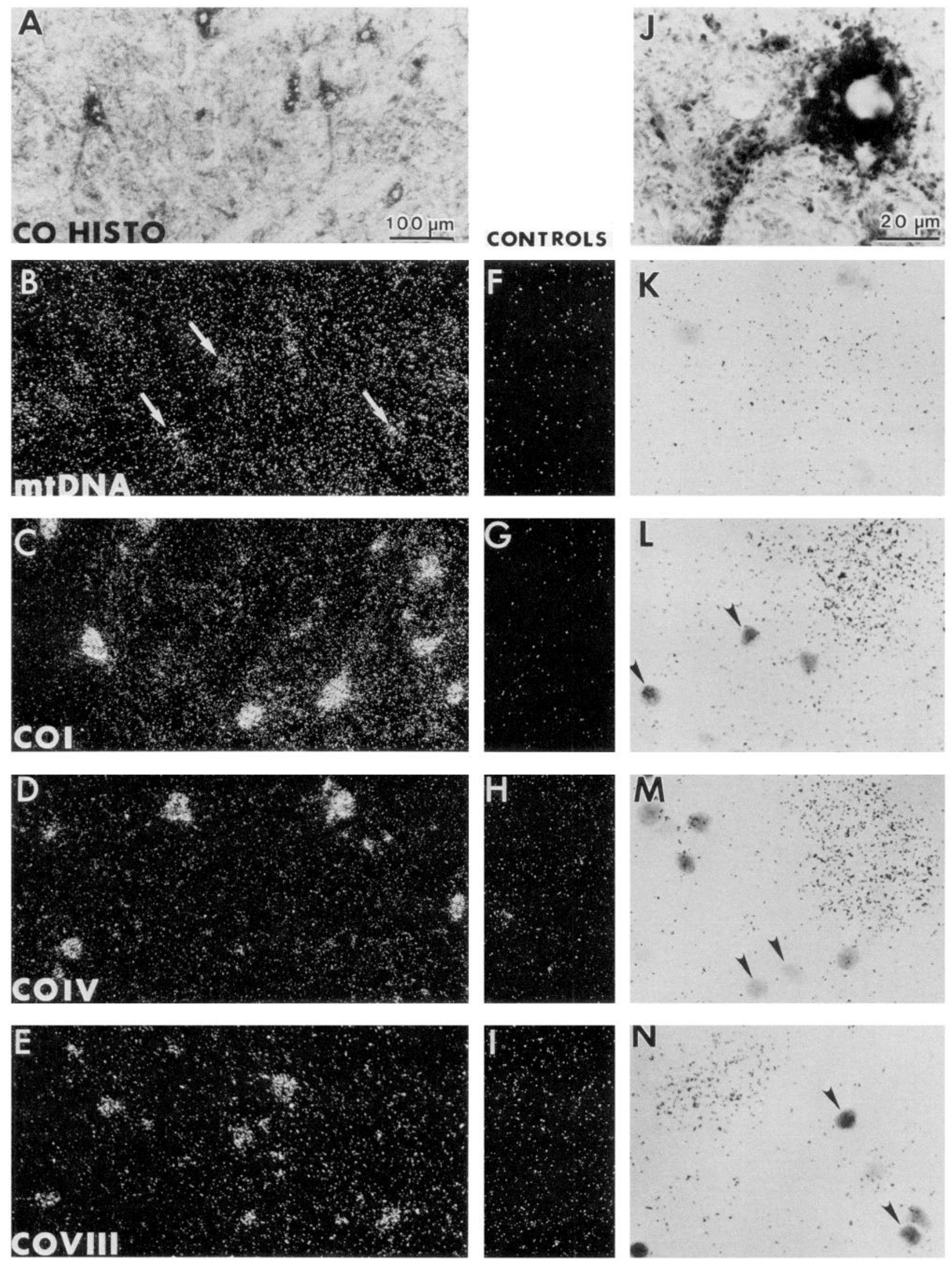

Figure 3. $\mathrm{CO}$ activity, mtDNA, and $\mathrm{CO}$ subunit mRNA in the deep cerebellar nuclei. $\mathrm{CO}$ activity, shown by histochemistry $(A, J)$, was highest in large neuronal cell bodies and proximal dendrites and was moderate in the neuropil. mtDNA $(B, K)$ was distributed throughout the neuropil, 
Detection of mtDNA. Modifications to the mRNA detection procedure were made as follows (see also Mita et al., 1989; Shoubridge et al., 1990): (1) Prehybridization treatments included digestion of RNA in the sections with RNAse A $\left(100 \mu \mathrm{g} / \mathrm{ml}\right.$ in $3 \times \mathrm{SSC}, 37^{\circ} \mathrm{C}, 30 \mathrm{~min}$, after fixation but before acetylation), inactivation of residual RNAse with fresh $0.1 \% \mathrm{DEPC}$ in $2 \times \mathrm{SSC}$ for $5 \mathrm{~min}$ at room temperature (Haase, 1987), and denaturation of DNA in the sections with $70 \%$ formamide and $0.2 \times \mathrm{SSC}$ at $75^{\circ} \mathrm{C}$ for $5 \mathrm{~min}$ just before ethanol dehydration (for control sections, no DNA denaturation step was included). (2) Hybridization was done at $39^{\circ} \mathrm{C}$ for $6 \mathrm{hr}$ with $\mathrm{COI}$ sense strand $(500 \mathrm{ng} / \mathrm{ml})$ rather than antisense strand $(250 \mathrm{ng} / \mathrm{ml})$; the higher probe concentration gave improved signals for mtDNA (Singer et al., 1987). (3) Posthybridization washes with $50 \%$ formamide and $2 \times \mathrm{SSC}$ were done at $39^{\circ} \mathrm{C}$.

Autoradiography. Dried sections were exposed to Kodak XAR-5 film for 3-5 d at room temperature. Films were developed with a standard processor. Slides were then dipped in Kodak NTB-3 emulsion (melted at $43^{\circ} \mathrm{C}$ with an equal volume of $0.3 \mathrm{~m}$ ammonium acetate), dried in a humid chamber, and exposed in the dark at $4^{\circ} \mathrm{C}$ for $4 \mathrm{~d}$ to $6 \mathrm{wk}$. Exposed slides were processed at $15^{\circ} \mathrm{C}$ for $3.5 \mathrm{~min}$ in Kodak Developer D-19, for $30 \mathrm{sec}$ in distilled water, and for $5 \mathrm{~min}$ in Kodak Fixer without acid hardener. The developed slides were dried, dehydrated through graded ethanols, cleared with xylene, and coverslipped with Permount (Fisher). Some sections were counterstained with cresyl violet, but the RNAse treatments used for in situ hybridization with riboprobes eliminated much of the Nissl staining, especially in large neurons with dispersed chromatin. Control sections were exposed to $x$-ray film in the same batch with experimental sections, then coated with emulsion and processed the same as experimental sections.

\section{Cytochrome oxidase histochemistry and immunohistochemistry}

Serial sections from the same blocks used for in situ hybridization were stained for CO activity by our usual method (Wong-Riley, 1979), modified for cryostat sections. Frozen, unfixed slide-mounted sections were finger thawed and immediately placed in Coplin jars containing fixative (3\% paraformaldehyde in $0.15 \mathrm{M} \mathrm{NaCl}, 0.1 \mathrm{M} \mathrm{NaP}, \mathrm{pH}$ 7) for $5 \mathrm{~min}$ at room temperature. The sections were rinsed four times with PBS, ther reacted for $\mathrm{CO}$. After reacting, sections were rinsed with PBS, postfixed in $8 \%$ formaldehyde overnight at $4^{\circ} \mathrm{C}$, rinsed with tap water, dried, dehydrated, cleared, and coverslipped. Some CO-reacted sections were counterstained with cresyl violet. Some $\mathrm{CO}$-stained sections were reacted for in situ hybridization, but riboprobe bound to the CO-reacted sections nonspecifically at unacceptable levels. [Mita et al. (1989) have combined $\mathrm{CO}$ histochemistry with in situ hybridization using DNA probes.] CO immunohistochemistry was done as described previously (Hevner and Wong-Riley, 1989), using free-floating sections from blocks different from those used for in situ hybridization.

\section{Results}

Human probe specificity versus monkey targets: Southern and Northern blots

We used blot hybridization to determine if our probes from human tissue would hybridize efficiently and specifically with monkey mtDNA and CO subunit mRNAs (Fig. 2). In Northern blots, each of the probes for mRNA (antisense transcripts) hybridized with a single band of monkey RNA at the appropriate size position expected based on $\mathrm{mRNA}$ size in humans (Fig. $2 A$ ). For all three subunits, the mRNA was the same size in monkey brain and heart, but was more abundant in heart. Also, each mRNA was polyadenylated, as shown by its enrichment in oligo-dT-bound fractions. The probe for mtDNA (COI sense strand) was tested in Southern blots and was found to be specific for mtDNA in monkey (Fig. $2 B$ ). 'The probe hybridized with restriction fragments from total DNA that were the same size as restriction fragments of purified monkey mtDNA. The relative signal intensities of the total DNA and purified mtDNA lanes indicated that the copy number of mtDNA was high in the total DNA (see Fig. $2 B$ caption).

\section{Specificity and sensitivity of in situ hybridization}

In all in situ hybridization experiments, appropriate controls were run in parallel to verify the specificity of the results. In experiments probing for mRNA, controls were hybridized with sense rather than antisense riboprobes. In mtDNA experiments, control sections were not exposed to DNA-denaturing conditions. Controls for both types of experiments showed only low levels of diffuse background labeling that did not form a pattern on films (not shown) or emulsions (Fig. 3). Background was slightly higher for COIV [ $56 \%$ guanine + cytosine (GC)] and COVIII (54\% GC) than for COI and mtDNA (both $44 \% \mathrm{GC}$ ), probably because the COIV and COVIII probes had higher GC contents and required longer exposure times after hybridization due to their smaller size. Also, the distributions of mRNA and mtDNA found by in situ hybridization were consistent with the distributions of $\mathrm{CO}$ activity and protein, taking into account differences in the intraneuronal compartmentalization of mRNA, mtDNA, and protein.

The relative hybridization signal intensities of each probe differed according to probe length, other conditions being identical. By varying autoradiographic exposure times, we were able to obtain similar grain densities for the different probes. Exposure times were shortest for mtDNA (4-12 d) and longer for COI (1-3 weeks), COIV (2-4 weeks), and COVIII (3-5 weeks) mRNAs. Other factors that might have affected signal intensities were hybridization efficiencies, extent of human-monkey sequence conservation (mismatches are degraded in the posthybridization RNAsc trcatment used in our procedure), and possibly target location (mitochondrial or cytosolic). These differences among probes prohibited us from making reliable quantitative estimates of the relative contents of mtDNA and CO subunit mRNAs in tissue. The possible effects of subunit isoforms and pseudogenes were considered negligible (see Discussion).

\section{Cellular expression of $\mathrm{CO}$ genes: neurons versus glia}

Control and experimental in situ hybridization results are shown for the deep cerebellar nuclei in Figure 3. The deep cerebellar nuclei contain large, darkly CO-reactive neurons, as well as many glia that are very low in $\mathrm{CO}$ activity. As shown by in situ hybridization, the neurons also contained more mtDNA and CO subunit mRNA than did the glia. Glia do contain mito-

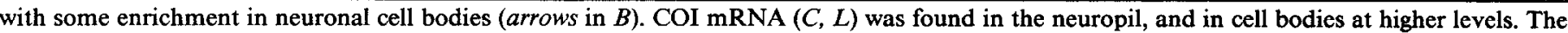

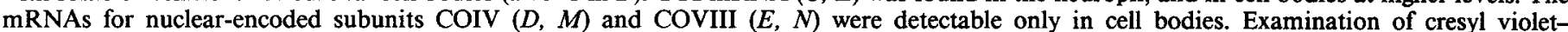

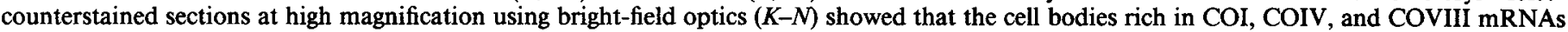

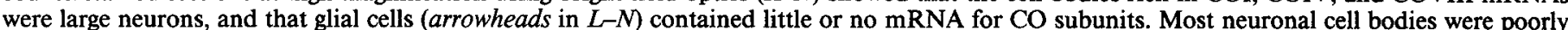

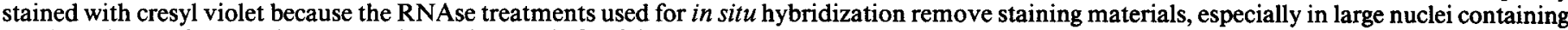

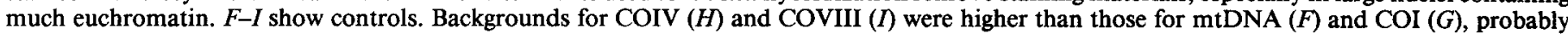

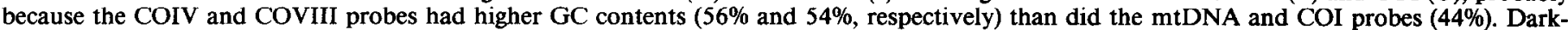
field optics were used for the emulsion autoradiograms shown in $B-I$. 


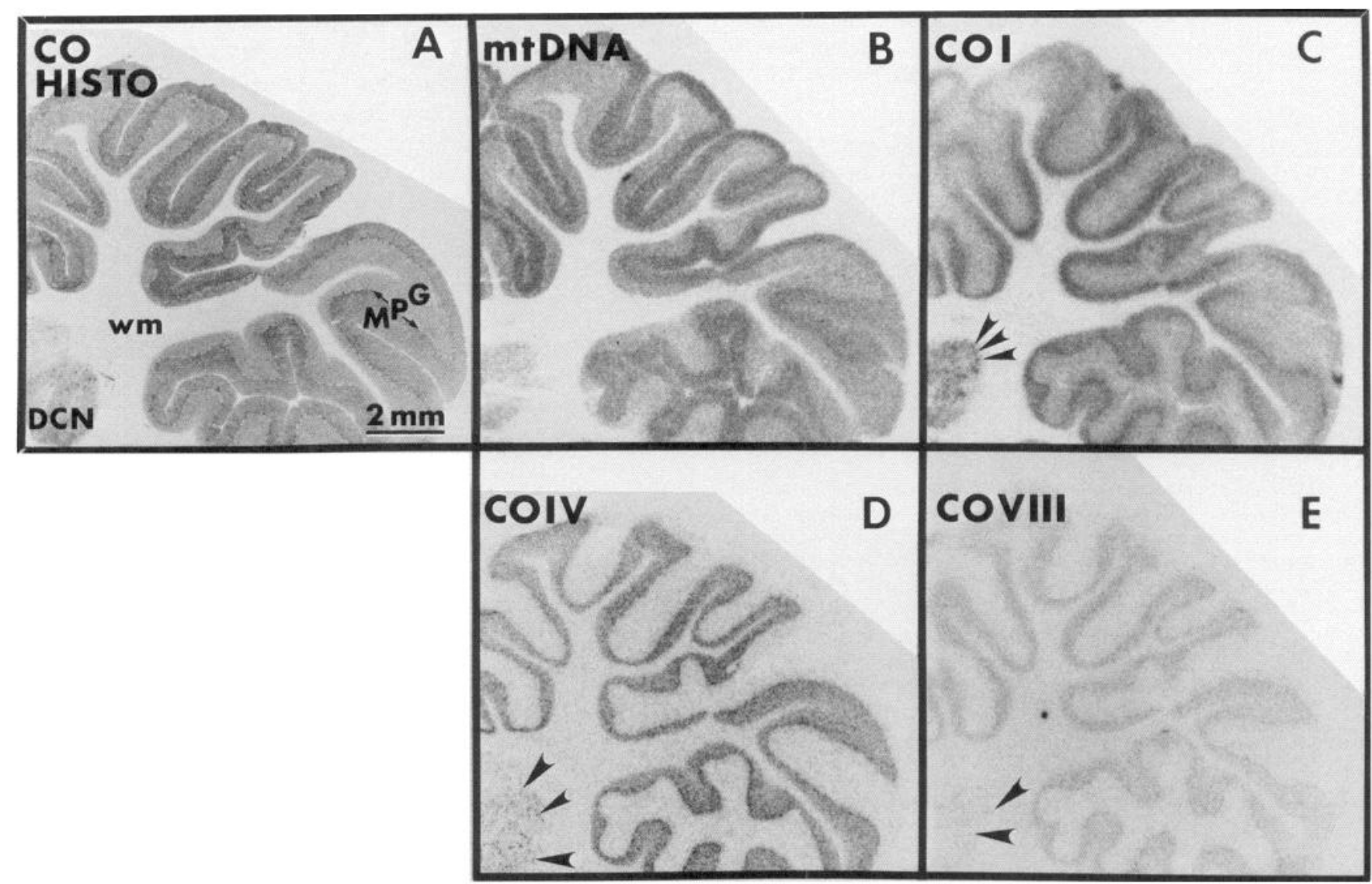

Figure 4. CO activity, mtDNA, and CO subunit mRNA in the cerebellum. CO histochemical activity $(A)$ was high in the cerebellar cortex and deep cerebellar nuclei $(D C N)$, and low in white matter $(w m)$. Within the cortex, the molecular layer $(M)$ was more darkly stained for overall CO activity than the granule cell layer $(G)$. mtDNA $(B)$ strongly resembled $C O$ in its distribution; it was most abundant in the molecular layer of the cortex and in the DCN. COI mRNA $(C)$ was highest in the granule cell layer and in neurons of the DCN (arrowheads), but was detectable in the molecular layer and in neuropil of the DCN. COIV $(D)$ and COVIII $(E)$ mRNA were detected only in cell bodies of the DCN $($ arrowheads) and cortex. Neuronal cell bodies in the granular as well as in the molecular layer of the cerebellar cortex were labeled for COIV and COVIII mRNA (see Fig. 5). $B-E$ show film autoradiograms. $P$, Purkinje cell layer.

chondria and $\mathrm{CO}$ that is low but detectable by cytochemistry, and must contain some mtDNA and CO subunit mRNA, but neurons clearly contained much more. In neurons, the mRNAs for COIV and COVIII were detected exclusively in cell bodies and proximal dendrites. COI mRNA was concentrated in the neuronal cell bodies, but was also clearly present at moderate levels in the neuropil. mtDNA was found throughout the neuropil, and at slightly more concentrated levels in neuronal cell bodies.

The signals for COI mRNA and mtDNA in neuropil could not be localized to neuronal or glial elements based only on morphology at the light microscopic level. However, the patterns of mtDNA and COI mRNA distribution were closely related to the pattern of $\mathrm{CO}$ distribution in all areas, and $\mathrm{CO}$ is concentrated in neurons (Wong-Riley, 1989). Also, mitochondria are most abundant in neurons. It is thus likely that mtDNA and COI mRNA in the neuropil were contained mostly in neuronal processes (especially dendrites) rather than glial elements.

\section{Neuronal expression of $\mathrm{CO}$ genes: axons versus dendrites versus cell bodies}

The intraneuronal, compartmental distributions of mtDNA and CO subunit mRNA were studied in the hippocampus and cer- ebellum. The distributions of $\mathrm{CO}$ activity and protein in these areas have been described in previous studies (Kageyama and Wong-Riley, 1982; Mjaatvedt and Wong-Riley, 1988; Hevner and Wong-Riley, 1989).

In all regions of hippocampus and cerebellum, the nuclearencoded mRNAs for COIV and COVIII were detected exclusively in cell bodies and proximal dendrites. If these mRNAs were present in other compartments (e.g., dendritic segments), their levels were not distinguishable from background in our experiments. In cerebellum, the highest levels of COIV and COVIII mRNA were found in the large neurons of the deep cerebellar nuclei (Figs. 3, 4) and the Purkinje cells (Fig. 5). Other neurons, such as granule cells, contained COIV and COVIII mRNAs at lower levels (Figs. 5, 6). In hippocampus (Figs. 79), labeling for COIV and COVIII mRNA was most intense in the pyramidal cell layer of region CA3. The CA3 pyramidal cells are also rich in CO activity (Kageyama and Wong-Riley, 1982) and protein (Hevner and Wong-Riley, 1989). Other neurons, such as the pyramidal cells of CA1, contained lower levels of $\mathrm{CO}$ activity, protein, and subunit mRNA. Cell bodies generally contained significant levels of COIV and COVIII mRNA even when they were low in $\mathrm{CO}$ activity and protein. Examples included the cell bodies of granule cells in the cerebellar cortex and of granule cells in the dentate gyrus. Overall, the distribu- 

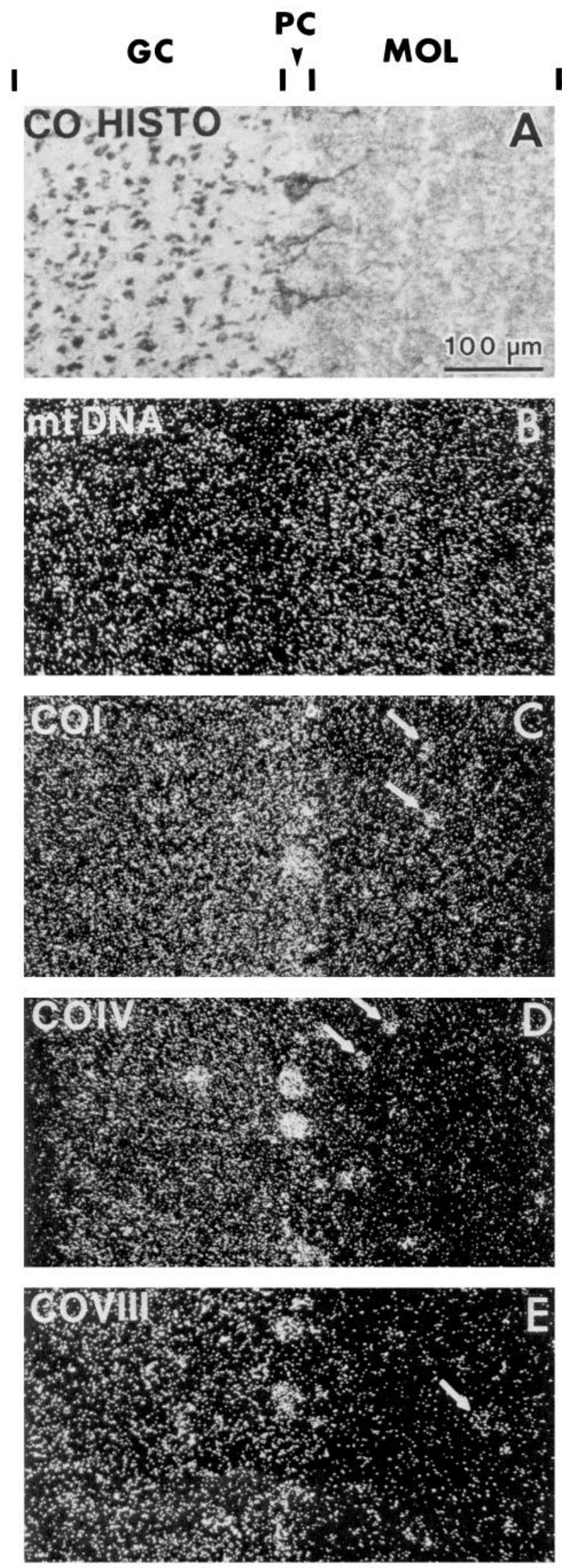

Figure 5. CO activity, mtDNA, and $\mathrm{CO}$ subunit mRNA in the cerebellar cortex. CO activity $(A)$ in the granule cell layer $(G C)$ was most tions of the two nuclear-encoded mRNAs were very similar to each other, but did not closely resemble the distributions of $\mathrm{CO}$ activity and protein, which were often found outside cell bodies, sometimes at high levels.

The mitochondrial-encoded mRNA (COI) was found at high levels in cell bodies, but was also clearly detected at moderate levels outside cell bodies and thus differed significantly from COIV and COVIII in its distribution. The highest levels of COI mRNA in cerebellum were found in neurons of the deep nuclei, and in hippocampus were found in the CA3 pyramidal cell layer. The presence of COI mRNA in dendrites was inferred from correlations between COI mRNA and CO histochemical activity in stratum lucidum (SL) of region CA3 in the hippocampus (Figs. 7, 8). In SL, CO activity is highest in the apical dendrites of CA3 pyramidal cells and lower in other elements of the neuropil (mostly mossy fiber axons and terminals), as previously shown by $\mathrm{CO}$ cytochemistry at the electron microscopic level (Kageyama and Wong-Riley, 1982). At the light microscopic level, bundles of the CA3 proximal apical dendrites are visible as darkly CO-stained strips passing through lightly CO-stained areas of SL, which correspond to mossy fiber axons, terminals, and other elements. The distribution of COI mRNA in SL showed a clear pattern of intensely labeled strips, representing the presumed apical dendrites of CA3 pyramidal cells that are also rich in $\mathrm{CO}$ activity (Fig. 8). COI mRNA was also clearly detected in presumed dendrites of other neuropil regions, including the molecular layer of the cerebellar cortex (Figs. 4, 5) and the molecular layer of the dentate gyrus (Figs. 7, 9).

Other observations indicated that axon terminals contained little or no COI mRNA, despite high levels of $\mathrm{CO}$ activity in some terminals. For example, synaptic glomeruli in the cerebellar granule cell layer are rich in mitochondria and $\mathrm{CO}$, but poor in COI mRNA (Fig. 6). Each synaptic glomerulus contains moderately CO-reactive dendrites from a few granule cells, as well as a single mossy fiber axon terminal filled with intensely CO-reactive mitochondria (Mjaatvedt and Wong-Riley, 1988; our own unpublished observations). Little or no signal for COI mRNA was observed in these presumed mossy fiber terminals by bright-field examination of Nissl-counterstained sections of the cerebellar granule cell layer (Fig. 6C). In contrast to axon terminals, neuronal cell bodies were rich in COI mRNA even when they were poor in $\mathrm{CO}$ activity. Examples of somata with

\section{$\leftarrow$}

intense in presumed mossy fiber terminals, interspersed among regions of low CO activity corresponding to granule cell bunches (Mjaatvedt and Wong-Riley, 1988; our own unpublished observations). The granule cell layer contained moderate levels of mtDNA $(B)$ and high levels of COI $(C)$, COIV $(D)$, and COVIII $(E)$ mRNAs. Purkinje cells $(P C)$ were clearly outlined by $\mathrm{CO}$ activity, found primarily in basket cell terminals surrounding their somata (Mjaatvedt and Wong-Riley, 1988). Their proximal dendrites were also $\mathrm{CO}$ reactive. Purkinje cell somata were not noticeably outlined by signal for mtDNA, but did contain high levels of COI, COIV, and COVIII mRNA. The molecular layer $(M O L)$, which contained high levels of $\mathrm{CO}$ activity distributed in fine puncta throughout the neuropil, was also rich in mtDNA. COI mRNA in the molecular layer was concentrated in cell bodies (arrows), but was also detected in the neuropil at lower levels. The mRNAs for COIV and COVIII in this layer were found only in cell bodies (arrows). The grains in the neuropil of the molecular layer were approximately background for COIV and COVIII; backgrounds were lower for mtDNA and COI (see Fig. 3). $B-$ $E$, emulsion autoradiograms photographed using dark-field optics. 

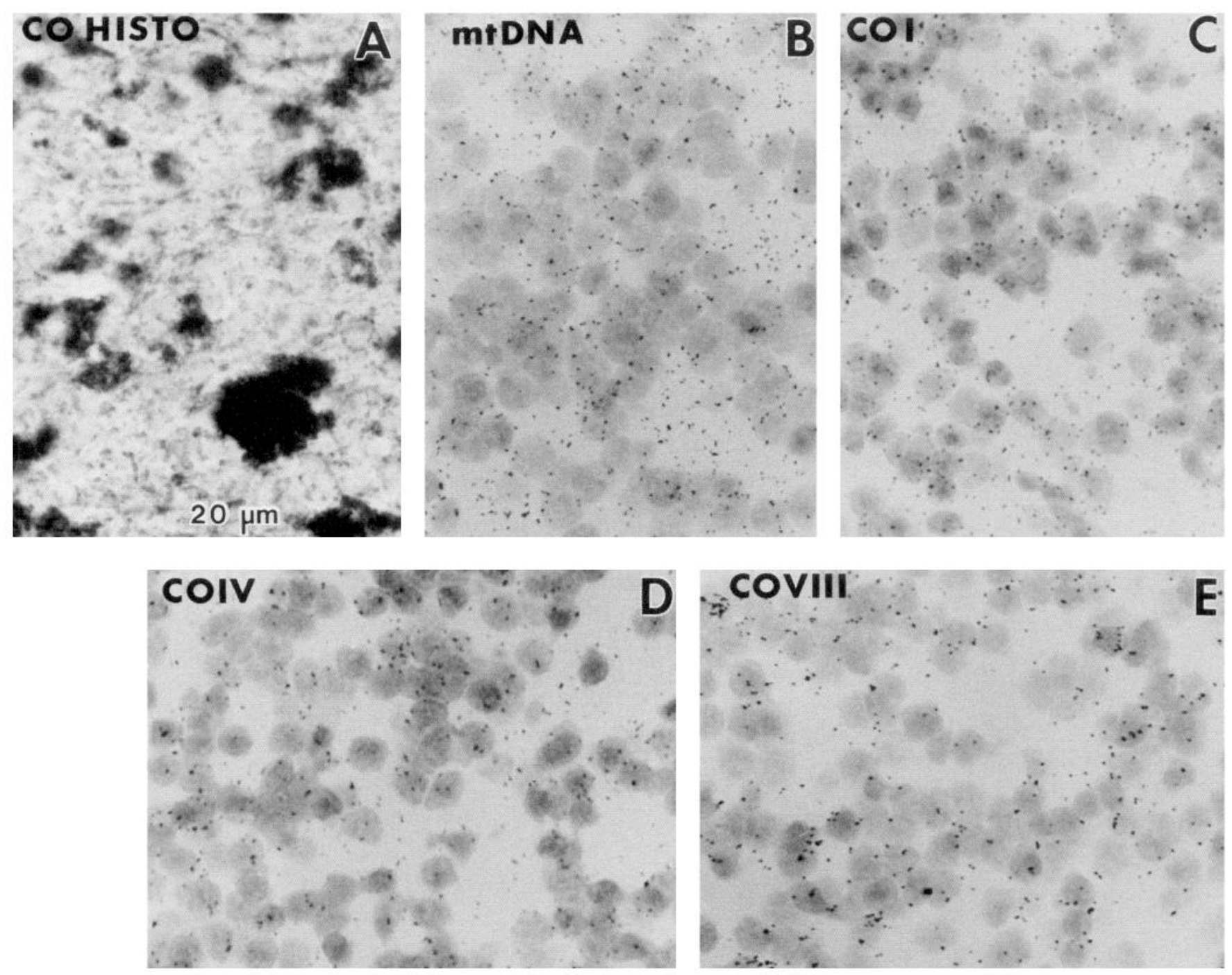

Figure 6. CO activity, mtDNA, and CO subunit mRNA in the granule cell layer of the cerebellar cortex. The large spots of CO activity $(A)$ correspond to synaptic glomeruli seen by electron microscopy (Mjaatvedt and Wong-Riley, 1988; our own unpublished observations). These synaptic glomeruli contain small granule cell dendrites and large mossy fiber axon terminals filled with mitochondria high in $\mathrm{CO}$ activity. The lightly COreactive regions, with few puncta of CO staining, correspond to granule cell bodies. Thus, cell bodies (low in CO activity) and axon terminals (rich in CO activity) are visibly segregated in this layer, even at the light microscopic level. In cresyl violet-counterstained sections $(B)$, mtDNA signal was found over cell bodies as well as in presumed mossy fiber terminals. The signals for COI $(C)$, COIV $(D)$, and COVIII $(E)$ mRNA were found almost exclusively over granule cell bodies, indicating that $\mathrm{CO}$ subunit mRNA (including mitochondrial-encoded COI) is absent or very low in presumed mossy fiber terminals. In contrast, mtDNA was present in the mossy fiber terminals, but was not as highly concentrated in them as was $\mathrm{CO}$ activity. Mitochondria in the mossy fiber terminals are rich in $\mathrm{CO}$ activity observed cytochemically at the electron microscopic level (our own unpublished observations).

low $\mathrm{CO}$ activity but high COI mRNA levels included the granule cells of the hippocampal dentate gyrus (Fig. $9 \mathrm{C}$ ) and the granule cells of the cerebellum (Fig. $6 \mathrm{C}$ ). Cell bodies with high $\mathrm{CO}$ activity, such as CA3 pyramidal cells and neurons of the deep cerebellar nuclei, also contained high levels of COI mRNA.

The strongest correlations to $\mathrm{CO}$ activity and protein were found for mtDNA. The overall distribution of mtDNA in both the cerebellum (Fig. 4) and the hippocampus (Fig. 7) closely resembled the distributions of $\mathrm{CO}$ activity and protein, as did the fine distribution of mtDNA seen at higher magnifications in most subregions and cell types. For example, dentate granule cells were low in $\mathrm{CO}$ activity and mtDNA in their cell bodies and high in CO activity and mtDNA in their presumed dendrites in the dentate molecular layer (Fig. 9). Likewise, in cerebellum, presumed mossy fiber axon terminals were rich in both mtDNA and $\mathrm{CO}$ activity (Fig. 6). The correlations between $\mathrm{CO}$ activity and $\mathrm{mtDNA}$ concentration were not, however, perfect. Regional differences in $\mathrm{CO}$ activity were sometimes not reflected as differences in mtDNA content. In the cerebellar granule cell layer, for example, $\mathrm{CO}$ activity was much higher in synaptic glomeruli than in granule cell bodies, but mtDNA levels were relatively high in both compartments (Fig. 6). Also, the apical dendrites of CA3 pyramids were intensely labeled for $\mathrm{CO}$ activity (and COI mRNA), but were not heavily labeled for mtDNA (Figs. $7,8)$. These disparities between the $\mathrm{CO}$ and mtDNA patterns suggest that $\mathrm{CO}$ activity may not always be proportional to mtDNA copy number, though we emphasize that in most cases $\mathrm{CO}$ activity did reflect mtDNA content. 

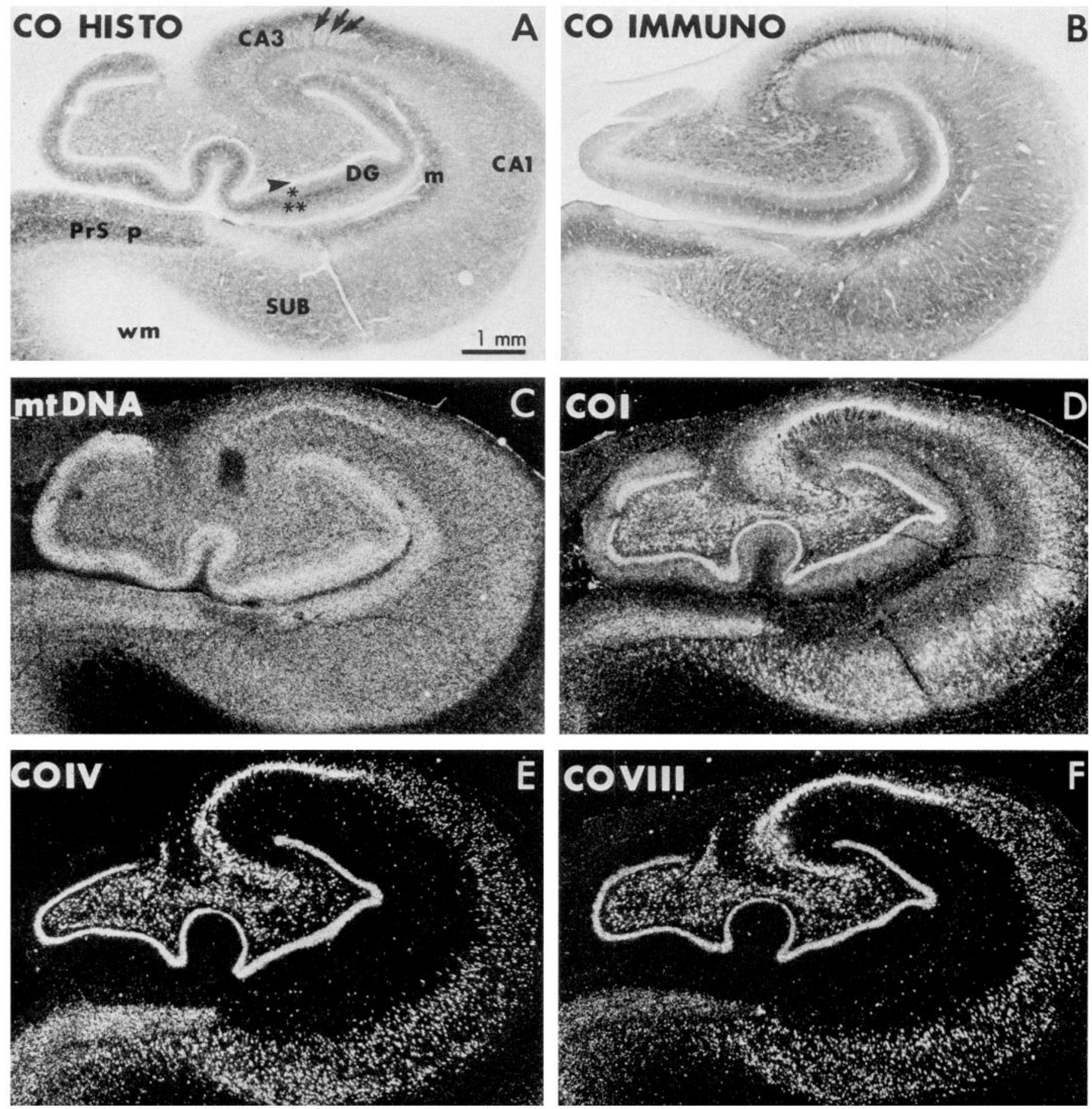

Figure 7. $\mathrm{CO}$ activity, $\mathrm{CO}$ amount, mtDNA, and $\mathrm{CO}$ subunit mRNA in the hippocampus. As in the cerebellum, $\mathrm{CO}$ activity $(A)$ is low in white matter $(\mathrm{wm})$ and high in gray matter (see also Hevner and Wong-Riley, 1989). In the dentate gyrus $(D G)$, granule cell bodies are low in CO activity (arrowhead), and the molecular layer is high in $\mathrm{CO}$ activity. Higher $\mathrm{CO}$ activity levels are found in the outer portion of the dentate molecular layer (double asterisk) than in the inner portion (single asterisk). In region CA3 of the hippocampus, pyramidal cells are rich in CO activity, as are bundles of their apical dendrites (arrows; identified by electron microscopy; Kageyama and Wong-Riley, 1982) that ascend through the otherwise lightly CO-reactive stratum lucidum. In region $C A 1$, there is a prominent band of high CO activity in the molecular layer $(\mathrm{m})$. The subiculum $(S U B)$ has moderate levels of $\mathrm{CO}$ activity. The presubiculum $(\operatorname{PrS})$ is darkly $\mathrm{CO}$ stained in its principal cell layer $(p)$. Each of these features of $\mathrm{CO}$ activity is also seen in the distribution of $\mathrm{CO}$ amount as shown by immunohistochemical staining for $\mathrm{CO}(B)$. The section in $B$ was not from the same block as the other sections shown. The pattern of mtDNA distribution $(C)$ was similar to that of CO activity and amount; note especially the molecular layer of $\mathrm{CA} 1$, the pyramidal cell layer of CA3, the dentate molecular layer, and the principal cell layer of the presubiculum. The distribution of COI mRNA $(D)$ in some ways resembled that of CO activity and amount (e.g., in the intense labeling of CA3 pyramidal cells and their apical dendrite bundles), but showed more intense labeling of cell bodies; note, for example, the dentate granule cell somata. The COIV (E) and COVIII $(F)$ mRNAs were detected exclusively in neuronal somata and proximal dendrites. $C-F$ show emulsion autoradiograms photographed with dark-field optics. 

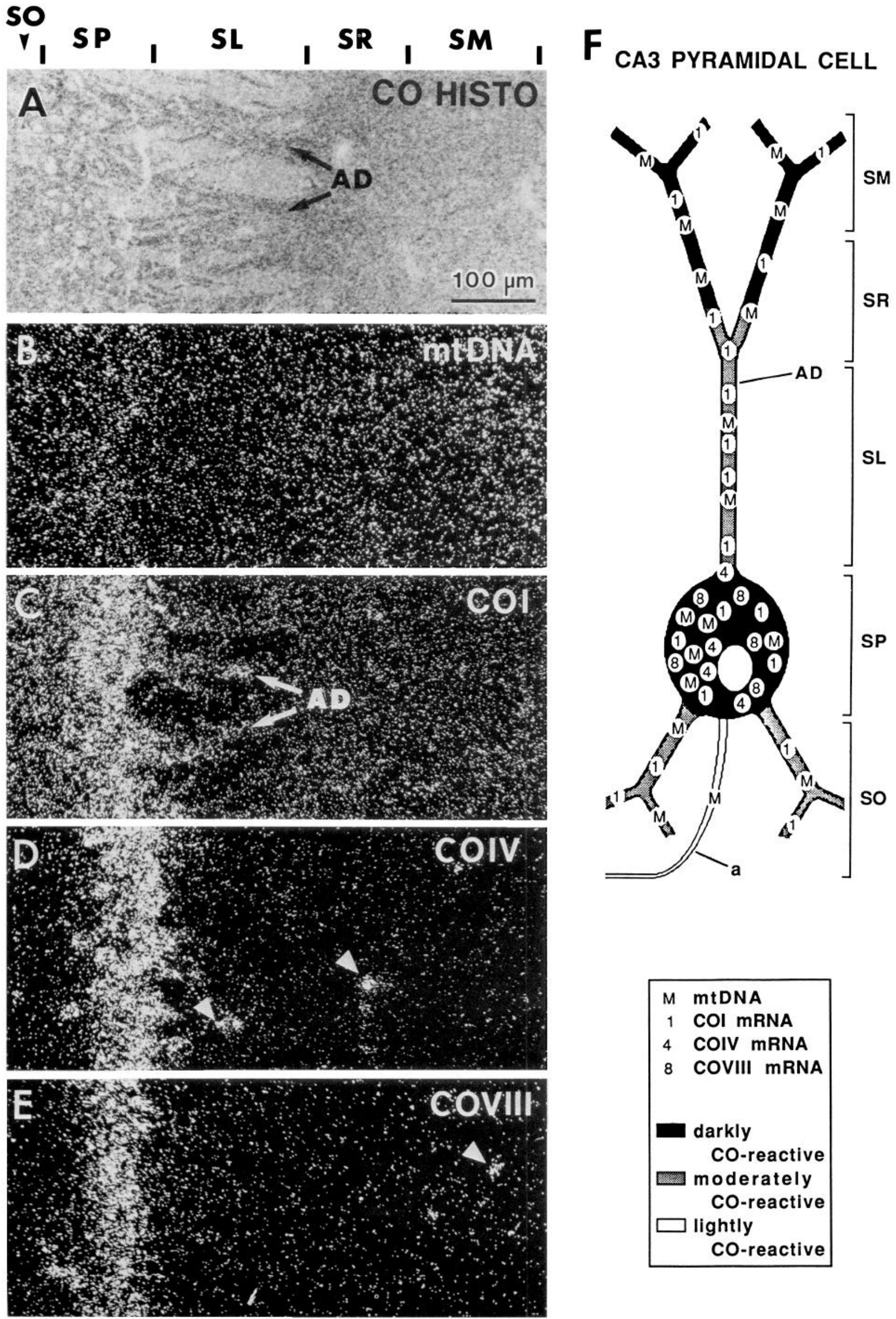
Regulation of mtDNA and CO subunit mRNA levels by neural functional activity

Regulation of $\mathrm{CO}$ was studied in the primary visual cortex (area 17) of adult macaque monkeys. Monocular TTX treatment was used to block impulse activity from one eye for 3-7 d and thus induce decreases in $\mathrm{CO}$ activity and protein in cortical ocular dominance columns corresponding to the treated eye (WongRiley and Carroll, 1984; Hevner and Wong-Riley, 1990). In the normal visual cortex, mtDNA and CO subunit mRNA levels varied by cortical layer, but within layers were constant across the cortical extent, except for variations in the levels of mtDNA and $\mathrm{COI}$ in layers 2 and 3 that correlated with $\mathrm{CO}$-rich puff and $\mathrm{CO}$-poor interpuff regions (shown for $\mathrm{COI}$ in Fig. 10). In cortex from TTX-treated animals, levels of mtDNA and of all three subunit mRNAs were decreased in the same ocular dominance columns that had low CO activity (shown for COI in Fig. 10). The changes in mtDNA and CO subunit mRNA, and in CO activity, were greatest in layer 4 , which primarily receives afferent input from the lateral geniculate nucleus.

\section{Summary of results}

Our results may be summarized as follows: (1) neurons contained more mtDNA and CO subunit mRNA than did glia; (2) the local concentration of mtDNA was closely, but not perfectly, related to $\mathrm{CO}$ activity; (3) mitochondrial-encoded COI mRNA was not proportional to mtDNA, but was relatively enriched in cell bodies and proximal dendrites and relatively depleted from axon terminal regions; (4) nuclear-encoded COIV and COVIII mRNAs were detected only in cell bodies and proximal dendrites and were strongly correlated with each other; and (5) regulation of $\mathrm{CO}$ activity by neural functional activity was associated with regulation of mtDNA content and with regulation of both nuclear- and mitochondrial-encoded $\mathrm{CO}$ subunit mRNA levels.

\section{Discussion}

In neurons, $\mathrm{CO}$ biosynthesis and regulation involve not only coordination between the nuclear and mitochondrial genomes, but also control over the local activity of the enzyme in each intraneuronal compartment. Previously, we showed that the local activity of $\mathrm{CO}$ in neurons largely or entirely reflects the distribution of CO protein (Hevner and Wong-Riley, 1989, 1990). In the present study, we found that the distributions of mtDNA, of mitochondrial-encoded $\mathrm{CO}$ subunit mRNA, of nuclear-encoded CO subunit mRNA, and of CO activity and protein are distinct, with varying degrees of similarity to each other. What are the implications of these results regarding mechanisms of $\mathrm{CO}$ biosynthesis and regulation?

\section{CO subunit isoforms and pseudogenes}

Isoforms (Kadenbach et al., 1987) and pseudogenes (e.g., Bachman et al., 1987; Lomax et al., 1990) have been demonstrated for some $\mathrm{CO}$ subunits in some species. The possibility that monkey isoforms and pseudogenes might influence our results was considered. If isoforms were present, our probes might not recognize all mRNA species encoding a subunit and thus might show only a partial picture of the total subunit mRNA distribution. However, our Northern blots suggested that only one isoform was present for the subunits (I, IV, and VIII) we studied. Only one size of each subunit mRNA was detected in both brain and heart (Fig. $2 A$ ). Other studies have also indicated that primate brain contains only one mRNA sizc cach for subunits IV (Zeviani et al., 1987) and VIII (Rizzuto et al., 1989). Also, Kamimura et al. (1989) detected no COI mRNA in human cytoplasmic RNA (macaque was not tested), indicating that all COI transcripts were mitochondrial and did not come from the nucleus, where the genes for isoforms of this mitochondrialencoded subunit would necessarily be located.

Pseudogenes would have affected our experiments to detect mtDNA only if the pseudogenes included COI sequences, because our probe for mtDNA was entirely from the COI gene. Pseudogenes including COI sequences have been found in human nuclear DNA (Kamimura et al., 1989), the closest species to macaque that has been studied. Also, Kristensen and Prydz (1986) reported the presence of intact mtDNA in nuclei from human cells. If COI pseudogene or nuclear mtDNA sequences were detected in our in situ hybridization experiments, their signals would be localized to nuclei. However, mtDNA signal in our experiments was often lowest in nuclei and cell bodies, and higher in neuropil (e.g., in the dentate gyrus). Furthermore, our Southern blots showed that the major signai in total brain DNA corresponded to authentic mtDNA (Fig. $2 B$ ). Our data thus indicate that, though it is possible that COI genes or pseudogenes hybridized with probe for mtDNA, the signal from these nuclear sequences was insignificant relative to the high copy number signal from authentic, mitochondrial mtDNA.

\section{$C O$ assembly and distribution}

Genes for 10 of $13 \mathrm{CO}$ subunits are found only in the nucleus, and not throughout the neuron like mitochondrial subunit genes. The nuclear-encoded subunits could be distributed to compartments distant from the nucleus by pre- and/or posttranslational mechanisms. Pretranslationally, mRNA could be transported into processes and then translated into protein. Alternatively, by a posttranslational mechanism, nuclear-encoded proteins could be translated from mRNA in the cell body and then transported to other compartments, either before or

Figure 8. CO activity, mtDNA, and CO subunit mRNA in region CA3 of the hippocampus. The principal neurons of this region, the CA3 pyramidal cells, are found in stratum pyramidale $(S P)$. They are rich in CO activity $(A)$, though this was more evident in Figure 7 ; the pattern of CO activity was partially obscured by freezing artifact in SP of the section shown here. Their apical dendrites $(A D)$ were grouped into bundles that were rich in CO compared to other elements of the stratum lucidum $(S L)$. The moderate to high levels of CO activity in the stratum oriens (SO), stratum radiatum $(S R)$, and stratum moleculare $(S M)$ likewise were due to CO mainly in dendrites of the CA3 pyramidal cells passing through these layers (see Kageyama and Wong-Riley, 1982). mtDNA $(B)$ was somewhat concentrated in the somata of CA3 pyramidal cells, but the proximal apical dendrites of these cells were not outlined by signal for mtDNA. In contrast, the CA3 pyramidal cell apical dendrites $(A D)$ in SL were clearly labeled for COI mRNA $(C)$, as were the somata of those cells in SP. COIV $(D)$ and COVIII $(E)$ mRNAs were, as in other regions, found only in neuronal cell bodies, mostly in SP but also in other layers (arrowheads). The diagram at right $(F)$ indicates the distributions of CO activity, mtDNA, and $\mathrm{CO}$ subunit mRNAs in a CA3 pyramidal cell based on the data in this figure and on the assumption that all of these markers were, like CO activity (Kageyama and Wong-Riley, 1982), located primarily in CA3 pyramidal cell elements and not in other tissue elements [diagram modified from Kageyama and Wong-Riley (1982)]. $B-E$, emulsion autoradiograms photographed with dark-field optics. $a$, axon. 

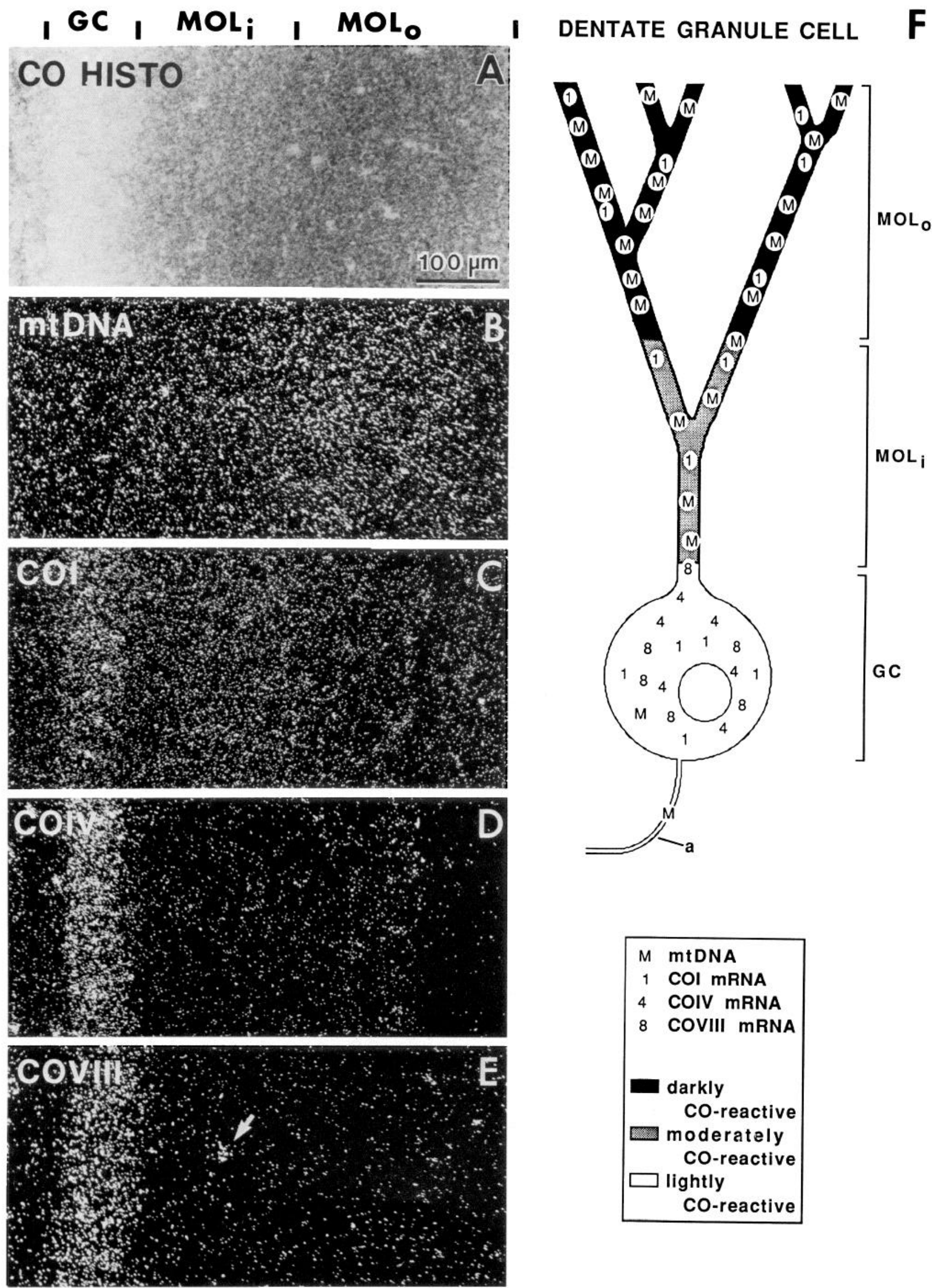
NORMAL

\section{PERPENDICULAR}

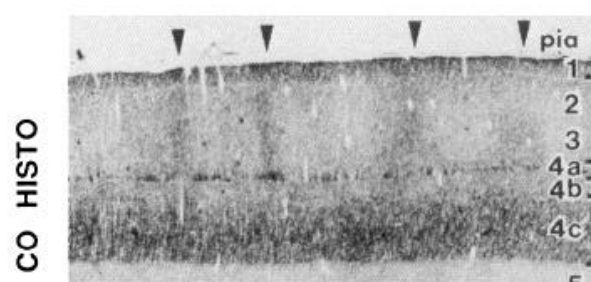

A $0.5 \mathrm{~mm}$

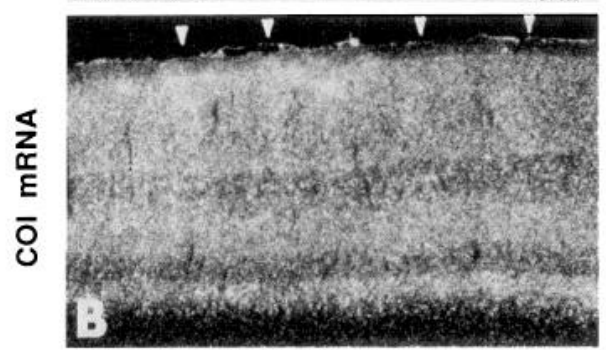

TTX

PERPENDICULAR
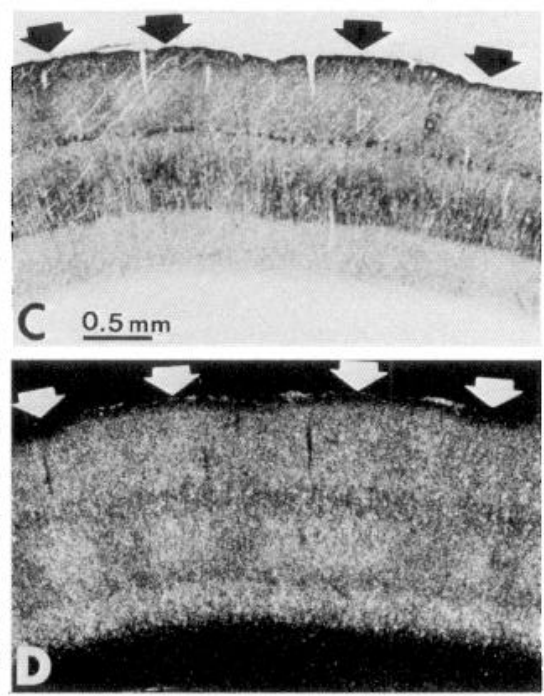

TANGENTIAL
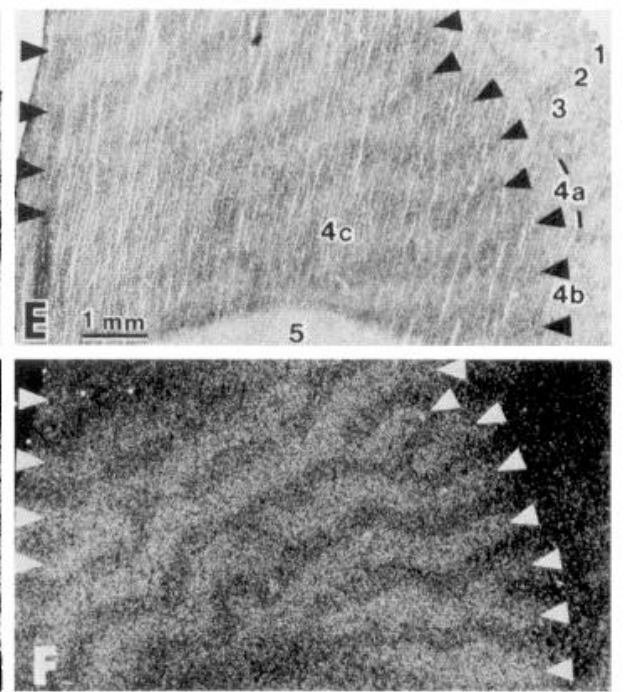

Figure 10. Regulation of mRNA encoding COI by functional activity in the macaque visual system. In normal area $17, \mathrm{CO}$ activity $(A)$ and $\mathrm{COI}$ mRNA levels $(B)$ are essentially constant within a cortical layer, except in layers 2 and 3 where the puffs or blobs (arrowheads in $A$ and $B$ ) contain more $\mathrm{CO}$ activity and COI mRNA than the interpuff regions. The puffs were also enriched for mtDNA, but not for mRNA encoding COIV or COVIII (data not shown). In cortex from animals treated monocularly with TTX for $7 \mathrm{~d}(C$ and $D)$ or $3 \mathrm{~d}(E$ and $F)$, CO activity $(C, E)$ and COI mRNA levels $(D, F)$ were normal in ocular dominance columns corresponding to the untreated eye (arrows in $C$ and $D$, arrowheads in $E$ and $F$ ) and decreased in columns corresponding to the treated eye. Similar results were obtained for mtDNA, and mRNA encoding COIV and COVIII (not shown). Cortical layers are indicated in $A$ and $E$ (numbers). The adjacent sections in $E$ and $F$ were cut tangential to the cortical surface to show the striped pattern of ocular dominance bands in layer $4 \mathrm{c}$ of the cortex after TTX treatment, while the other sections shown were cut perpendicular to the cortical surface and pass through all cortical layers. Bright-field optics were used for $A, C$, and $E$, and dark-field optics for $B$, $D$, and F. pia, pia mater; wm, white matter.

after incorporation into mitochondria. The posttranslational model is consistent with observations that the cell body and proximal dendrites contain most of the ribosomes in the neuron and are the main sites of protein synthesis. However, pretranslational models cannot be ruled out on this basis, because ribosomes are also found (in lower numbers) in dendrites (Steward and Falk, 1986), and mRNA transport into dendrites has been documented for some mRNAs (Garner et al., 1988; Burgin et al., 1990). Our results support the posttranslational model for distribution of nuclear-encoded $\mathrm{CO}$ subunits, because the mRNAs for COIV and COVIII were localized mainly or exclusively in the cell bodies and proximal dendrites of neurons, not in axons or dendrites beyond the most proximal segments.

We cannot determine from our results whether newly synthesized nuclear-encoded polypeptides are transported to processes before or after incorporation into mitochondria. Pulsechase studies of mitochondrial protein uptake in yeast cells (Reid and Schatz, 1982; Reid et al., 1982), in chicken embryo fibroblasts (Jaussi et al., 1982), and in rat hepatocytes (Mori et al., 1981) have indicated that mitochondrial proteins are imported into mitochondria rapidly, within 1-2 min of synthesis. In neurons, import this rapid would allow little time for transport prior to incorporation, and proteins would be imported primarily by mitochondria in the cell body. To determine experimentally if import occurs in the cell body, one could make use of the fact that most nuclear-encoded mitochondrial proteins initially contain presequences that are proteolytically removed upon import (Attardi and Schatz, 1988). If mitochondrial protein import occurs only in the soma, and if presequence cleavage and degradation are not slow, then presequences should be found only in cell bodies. Presequences could be localized by immunohistochemistry.

Because mitochondria are located throughout the neuron and contain their own genetic apparatus, we initially hypothesized

$\leftarrow$

Figure 9. CO activity, mtDNA, and CO subunit mRNA in the dentate gyrus. The principal cells of this region are the granule cells found in the granule cell layer $(G C)$. The somata of these cells were low in CO activity $(A)$ and mtDNA $(B)$, but contained high concentrations of COI $(C)$, COIV $(D)$, and COVIII $(E)$ mRNAs. In the molecular layer, which contains few somata and comprises mostly neuropil, CO activity and mtDNA levels were moderate in the inner portion $\left(M O L_{i}\right)$ and high in the outer portion $\left(M O L_{o}\right)$. The level of mitochondrial-encoded COI mRNA was moderate throughout the molecular layer, indicating the likely presence of COI mRNA in granule cell dendrites, which have most of the CO activity in the molecular layer (Kageyama and Wong-Riley, 1982). COIV and COVIII mRNA were not detected in the molecular layer (the grains in this layer being at background level for these probes), except for their presence in occasional neuronal cell bodies in that layer (arrow in $E$ ). $D$ shows a region of the dentate gyrus that was thinner than in the other sections shown; an area of slide without tissue is visible at the far right. Note that the background was higher over tissue than over slide without tissue. The diagram at right $(F)$ summarizes the distributions of CO activity, mtDNA, and CO subunit mRNAs in dentate granule cells based on the data shown here and on the assumption that all of these markers are, like CO activity (Kageyama and Wong-Riley, 1982), mostly found in granule cell elements [diagram modified from Kageyama and Wong-Riley (1982)]. $B-E$, emulsion autoradiograms photographed using dark-field optics. $a$, axon. 


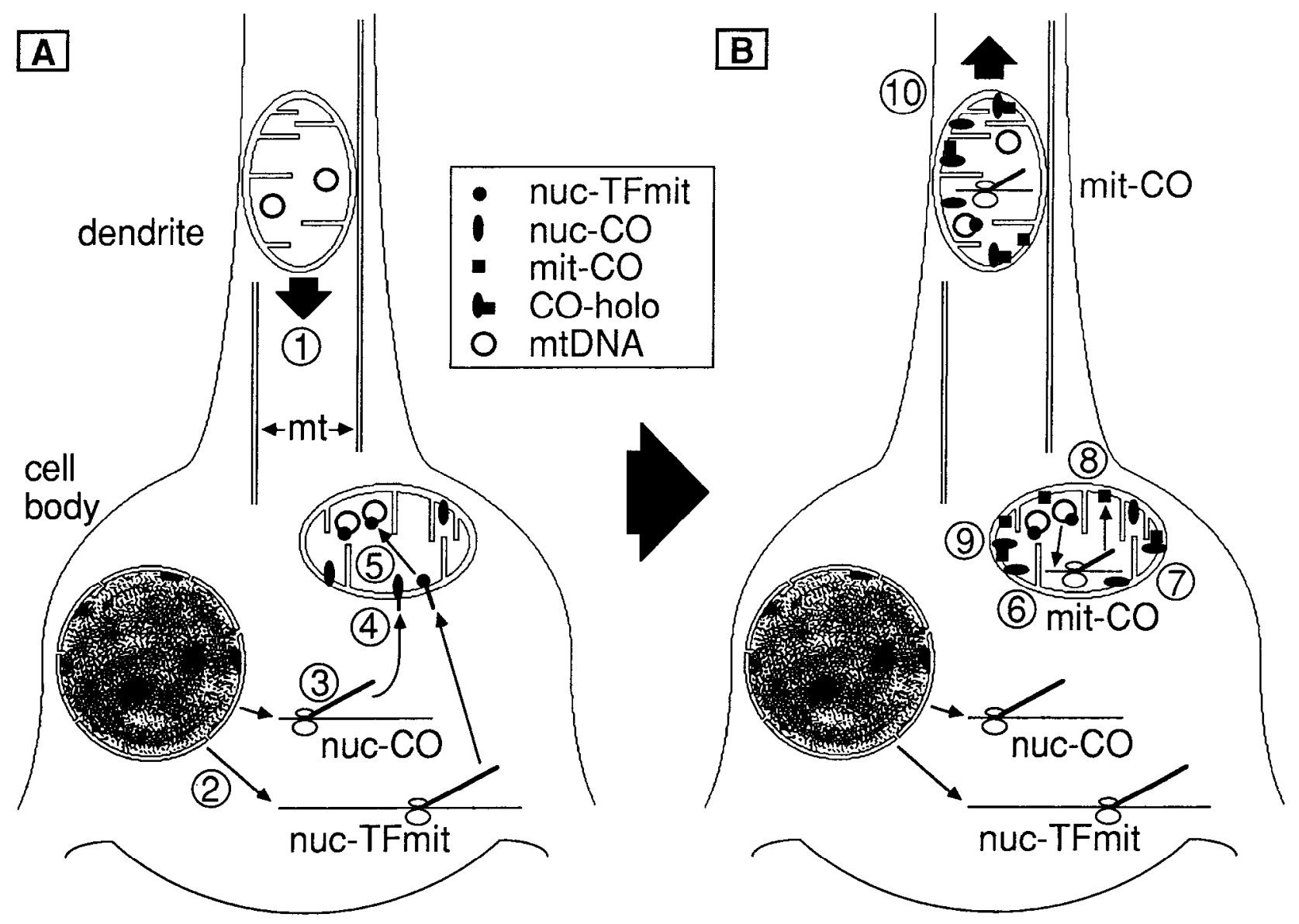

Figure 11. Model for synthesis, assembly, and distribution of $\mathrm{CO}$ in neurons. The model presents implications based on results regarding the distributions of mtDNA and CO subunit mRNAs, as well as postulated mechanisms to explain the mRNA and mtDNA distributions. Postulated mechanisms include the rapid transport of mitochondria along microtubules and the stimulation of mtDNA transcription by nuclear-encoded factors synthesized mainly in the soma. $A$, Mitochondria are transported along microtubules $(m t)$ to the cell body $(l)$. The mRNAs for nuclearencoded $\mathrm{CO}$ subunits (nuc-CO) and other nuclear-encoded mitochondrial proteins, such as the mitochondrial transcription factors (nuc-TFmit), are expressed in the cell body (2). (The distributions of nuclear-encoded mRNAs for mitochondrial gene expression proteins have not been determined experimentally, but are proposed to be mainly in cell bodies, like COIV and COVIII mRNAs.) Following translation (3), the nuclear-encoded mitochondrial proteins are imported into the mitochondria (4). The nuclear-encoded mitochondrial transcription factors bind to the mtDNA and stimulate mtDNA gene expression in the cell body (5). $B$, Stimulation of mtDNA gene expression leads to transcription (6) and translation (7) of the mRNAs for mitochondrial-encoded $\mathrm{CO}$ subunits $($ mit $-\mathrm{CO})$ and other mitochondrial gene products. The mitochondrial-encoded proteins are inserted into the inner mitochondrial membrane ( 8 ). Assembly of $\mathrm{CO}$ holoenzyme ( $\mathrm{CO}$-holo) occurs by binding of nuclear- and mitochondrialencoded CO subunits in the inner mitochondrial membrane (9). Expression of mitochondrial genes and assembly of CO holoenzyme continue as mitochondria are transported away from the cell body $(10)$, until the mitochondrial mRNAs, and the proteins stimulating mitochondrial gene expression, are degraded.

that COI mRNA might also be found throughout the neuron, with a distribution similar to that of mIDNA or $\mathrm{CO}$ activity and protein. However, COI mRNA was not well correlated with mtDNA or CO activity and protein, nor was COI mRNA well correlated with COIV and COVIII mRNA. Instead, COI mRNA showed a unique distribution that was generally high in cell bodies, lower in dendrites, and very low or nil in axon terminals. This may indicate that factors encoded in the nucleus stimulated COI gene expression mainly in cell bodies, and to a lesser degree in dendrites. This explanation seems reasonable because most mitochondrial gene expression proteins, including mitochondrial RNA polymerase (Kelly et al., 1986; Masters et al., 1987) and mitochondrial transcription factor 1 (Fisher et al., 1989), are encoded in nuclear genes (Attardi and Schatz, 1988). These nuclear-encoded proteins may be present at highest concentrations in cell bodies, if they are (like COIV and COVIII) syn- thesized in the soma, and turn over somewhat rapidly. This hypothesis could be tested experimentally using immunohistochemistry and in situ hybridization to localize nuclear-encoded protcins for mitochondrial gene expression and their mRNAs.

Our data suggest that most CO holoenzyme assembly probably occurs in the cell body, because most $\mathrm{CO}$ subunit synthesis occurs there. However, a significant amount of COI mRNA is found in dendrites. Assembly of $\mathrm{CO}$ holoenzyme might occur in dendrites if free nuclear-encoded $\mathrm{CO}$ subunits were available to combine with mitochondrial-encoded (COI, COII, COIII) subunit protein synthesized in dendrites. The nuclear-encoded subunits would be available if they were incorporated in slight excess of mitochondrial requirements in the cell body and remained active during mitochondrial transport into dendrites. This idea is consistent with the results of Mita et al. (1989), who found that COIV was immunohistochemically detectable at es- 
sentially normal levels in human muscle mitochondria even when mitochondrial-encoded $\mathrm{CO}$ subunits were depleted due to an mtDNA mutation. Also, $\mathrm{CO}$ subunits in yeast can accumulate in the absence of holoenzyme assembly (Forsburg and Guarente, 1989).

Our results imply that mitochondria must be periodically shuttled to and from the cell body region to obtain newly synthesized nuclear-encoded mitochondrial proteins. Mitochondria are transported in neurons by a mechanism involving microtubules (Vale et al., 1985). The rate of mitochondrial transport, estimated in studies of anterograde transport in rabbit retinal ganglion cell axons, is about $0.58 \mu \mathrm{m} / \mathrm{sec}$, or $5 \mathrm{~cm} / \mathrm{d}$ (Lorenz and Willard, 1978). Mitochondrial transport thus allows for the relatively rapid distribution of nuclear-encoded mitochondrial proteins from the soma. Proteins not associated with organelles are transported more slowly, on the order of $1 \mathrm{~mm} / \mathrm{d}$ (Vale, 1987). Mitochondrial transport may be regulated according to metabolic demand, because the distribution of $\mathrm{CO}$ protein is not homogeneous within neurons (Hevner and Wong-Riley, 1989, 1990).

In sum, our results support the following model for $\mathrm{CO}$ assembly and distribution in neurons (Fig. 11). The mRNAs for nuclear-encoded CO subunits and for nuclear-encoded mitochondrial gene expression proteins are translated in the soma. The newly translated polypeptides are then rapidly imported into mitochondria in the soma. The gene expression proteins stimulate synthesis of mitochondrial-encoded $\mathrm{CO}$ subunit mRNAs. The gene expression proteins and mitochondrial mRNAs remain active in the mitochondria as they are transported out of the soma, but eventually turn over, depleting mitochondria distant from the soma of their mRNAs and gene expression proteins. Most $\mathrm{CO}$ is thus assembled in the cell body, but some assembly occurs in dendrites as newly synthesized mitochondrial-encoded subunits combine with free nuclear-encoded subunits imported in excess while the mitochondria were in the cell body. Mitochondrial transport provides for the rapid distribution of nuclear-encoded mitochondrial proteins, and for the periodic return of mitochondria to the soma for new protein incorporation.

\section{Regulation of $\mathrm{CO}$ activity}

We previously showed that changes in $\mathrm{CO}$ activity, induced using the TTX paradigm in the monkcy visual systcm, were due to changes in CO protein levels (Hevner and Wong-Riley, 1990). In the present study, we found that changes in $\mathrm{CO}$ protein levels are, in turn, related to changes in mtDNA and $\mathrm{CO}$ subunit mRNA levels. These results suggest that regulation of gene expression and mtDNA copy number are the primary mechanisms of $\mathrm{CO}$ activity regulation in neurons. $\mathrm{mtDNA}$ and $\mathrm{CO}$ subunit mRNA levels are also regulated in muscle, by contractile activity (Williams, 1986; Williams et al., 1986, 1987; Hood et al., 1989).

Several questions remain concerning $\mathrm{CO}$ gene regulation. The degree of coordination between the nuclear and mitochondrial genomes is unknown. Are changes in the levels of nuclear- and mitochondrial-encoded subunit mRNAs proportional, or is one class of mRNAs more strongly regulated? Studies of muscle have given conflicting answers to this question (Williams, 1986; Williams et al., 1986, 1987; Hood et al., 1989). Also, are changes in mitochondrial mRNA levels due simply to changes in the copy number of mtDNA in mitochondria, or are transcription and mRNA stability also regulated? Williams (1986) has proposed that changes in mtDNA copy number are the major reg- ulatory event. Other investigators have emphasized the importance of signals from the nucleus in control of mitochondrial gene expression (Piko and Taylor, 1987; El Meziane et al., 1989). Quantitative comparisons of CO activity, $\mathrm{CO}$ amount, mtDNA, and mRNA levels must be done to answer these questions.

Mechanisms other than regulation of gene expression may also play a role in controlling $\mathrm{CO}$ activity. One possibility is that $\mathrm{CO}$ activity is regulated conformationally by ATP, though the physiological significance of this mechanism has not yet been demonstrated (Huther and Kadenbach, 1986; Bisson et al., 1987; Gai et al., 1988). Interestingly, we have found that the cytochemical activity of $\mathrm{CO}$ in neuronal mitochondria is variable: some mitochondria are rich in $\mathrm{CO}$, and others have little $\mathrm{CO}$ activity (Kageyama and Wong-Riley, 1982; Carroll and WongRiley, 1984). What determines the $\mathrm{CO}$ activity of individual mitochondria? One possibility is that mitochondria may vary in their content of mtDNA, because mtDNA levels were usually well correlated with $\mathrm{CO}$ activity. Tests of this idea must await technical developments in methods such as electron microscopic in situ hybridization.

\section{References}

Anderson S, Bankier AT, Barrell BG, de Bruijn MHL, Coulson AR, Drouin I, Eperon IC, Nierlich DP, Roe BA, Sanger F, Schreier PH, Smith AJH, Staden R, Young IG (1981) Sequence and organization of the human mitochondrial genome. Nature 290:457-465.

Attardi G, Schatz G (1988) Biogenesis of mitochondria. Annu Rev Cell Biol 4:289-333.

Bachman NJ, Lomax MI, Grossman LI (1987) Two bovine genes for cytochrome $c$ oxidase subunil IV: a processed pseudogene and an expressed gene. Gene 55:219-229.

Bisson R, Schiavo G, Montecucco C (1987) ATP induces conformational changes in mitochondrial cytochrome $c$ oxidase. Effect on the cytochrome $c$ binding site. J Biol Chem 262:5992-5998.

Blin N, Stafford DW (1976) A general method for isolation of high molecular weight DNA from eukaryotes. Nucleic Acids Res 3:23032308.

Bogenhagen D, Clayton DA (1974) The number of mitochondrial deoxyribonucleic acid genomes in mouse $\mathrm{L}$ and human HeLa cells. Quantitative isolation of mitochondrial deoxyribonucleic acid. J Biol Chem 249:7991-7995.

Burgin KE, Waxham MN, Rickling S, Westgate SA, Mobley WC, Kelly PT (1990) In situ hybridization histochemistry of $\mathrm{Ca}^{2+} /$ calmodulindependent protein kinase in developing rat brain. J Neurosci 10:17881798.

Carroll EW, Wong-Riley MTT (1984) Quantitative light and electron microscopic analysis of cytochrome oxidase-rich zones in the striate cortex of the squirrel monkey. J Comp Neurol 222:1-17.

Chesselet M-F, Weiss L, Wuenschell C, Tobin AJ, Affolter H-U (1987) Comparative distribution of $\mathrm{mRNAs}$ for glutamic acid decarboxylase, tyrosine hydroxylase, and tachykinins in the basal ganglia: an in situ hybridization study in the rodent brain. J Comp Neurol 262:125140.

Chomczynski P, Sacchi N (1987) Single-step method of RNA isolation by acid guanidinium thiocyanate-phenol-chloroform extraction. Anal Biochem 162:156-159.

Dietrich WD, Durham D, Lowry OH, Woolsey TA (1981) Quantitative histochemical effects of whisker damage on single identified cortical barrels in the adult mouse. J Neurosci 1:929-935.

Dietrich WD, Durham D, Lowry OH, Woolsey TA (1982) "Increased" sensory stimulation leads to changes in energy-related enzymes in the brain. J Neurosci 2:1608-1613.

El Meziane A, Callen J-C, Mounolou J-C (1989) Mitochondrial gene expression during Xenopus laevis development: a molecular study. EMBO J 8:1649-1655.

Erecinska M, Silver IA (1989) ATP and brain function. J Cereb Blood Flow Metab 9:2-19.

Fisher RP, Parisi MA, Clayton DA (1989) Flexible recognition of rapidly evolving promoter sequences by mitochondrial transcription factor 1. Genes Dev 3:2202-2217. 
Forsburg SL, Guarente L (1989) Communication between mitochondria and the nucleus in regulation of cytochrome genes in the yeast Saccharomyces cerevisiae. Annu Rev Cell Biol 5:153-180.

Gai W-Z, Sun S-M, Ding Y-Z, Freedman JA, Chan SHP (1988) Two monoclonal antibody lines directed against subunit IV of cytochrome oxidase: a study of opposite effects. Arch Biochem Biophys 266:628638.

Garner CC, Tucker RP, Matus A (1988) Selective localization of messenger RNA for cytoskeletal protein MAP2 in dendrites. Nature 336: $674-677$.

Haase AT (1987) Analysis of viral infections by in situ hybridization. In: In situ hybridization: applications to neurobiology (Valentino KL, Eberwine JH, Barchas JD, eds), pp 197-219. New York: Oxford UP.

Hevner RF, Wong-Riley MTT (1989) Brain cytochrome oxidase: purification, antibody production, and immunohistochemical/histochemical correlations in the CNS. J Neurosci 9:3884-3898.

Hevner RF, Wong-Riley MTT (1990) Regulation of cytochrome oxidase protein levels by functional activity in the macaque monkey visual system. J Neurosci 10:1331-1340.

Hood DA, Zak R, Pette D (1989) Chronic stimulation of rat skeletal muscle induces coordinate increases in mitochondrial and nuclear mRNAs of cytochrome-c-oxidase subunits. Eur J Biochem 179:275280.

Horton JC, Hubel DH (1981) Regular patchy distribution of cytochrome oxidase staining in primary visual cortex of macaque monkey. Nature 292:762-764.

Huther F-J, Kadenbach B (1986) Specific effects of ATP on the kinetics of reconstituted bovine heart cytochrome- $c$ oxidase. FEBS Lett 207: 89-94.

Jaussi R, Sondercgger P, Fluckiger J, Christen P (1982) Biosynthesis and topogenesis of aspartate aminotransferase isoenzymes in chicken embryo fibroblasts. The precursor of the mitochondrial isoenzyme is either imported into mitochondria or degraded in the cytosol. J Biol Chem 257:13334-13340.

Kadenbach B, Jarausch J, Hartmann R, Merle P (1983) Separation of mammalian cytochrome $c$ oxidase into 13 polypeptides by a sodium dodecyl sulfate-gel electrophoretic procedure. Anal Biochem 129: $517-521$.

Kadenbach B, Kuhn-Nentwig L, Buge U (1987) Evolution of a regulatory enzyme: cytochrome- $c$ oxidase (complex IV). Curr Top Bioenerg 15:113-161.

Kageyama GH, Wong-Riley MTT (1982) Histochemical localization of cytochrome oxidase in the hippocampus: correlation with specific neuronal types and afferent pathways. Neuroscience 7:2337-2361.

Kamimura N, Ishii S, Liandong M, Shay JW (1989) Three separate mitochondrial DNA sequences are contiguous in human genomic DNA. J Mol Biol 210:703-707.

Kelly JL, Greenleaf AL, Lehman IR (1986) Isolation of the nuclear gene encoding a subunit of the yeast mitochondrial RNA polymerase. J Biol Chem 261:10348-10351.

Kristensen T, Prydz H (1986) The presence of intact mitochondrial DNA in HeLa cell nuclei. Nucleic Acids Res 14:2597-2609.

Livingstone MS, Hubel DH (1984) Anatomy and physiology of a color system in the primate visual cortex. J Neurosci 4:309-356.

Lomax MI, Welch MD, Darras BT, Francke U, Grossman LI (1990) Novel use of a chimpanzee pseudogene for chromosomal mapping of human cytochrome $c$ oxidase subunit IV. Gene 86:209-216.

Lorenz T, Willard M (1978) Subcellular fractionation of intra-axonally transported polypeptides in the rabbit visual system. Proc Natl Acad Sci USA 75:505-509.

Masters BS, Stohl LL, Clayton DA (1987) Yeast mitochondrial RNA polymerase is homologous to those encoded by bacteriophages T3 and T7. Cell 51:89-99.

Mawe GM, Gershon MD (1986) Functional heterogeneity in the myenteric plexus: demonstration using cytochrome oxidase as a verified cytochemical probe of the activity of individual enteric neurons. J Comp Neurol 249:381-391.

Mita S, Schmidt B, Schon EA, DiMauro S, Bonilla E (1989) Detection of "deleted" mitochondrial genomes in cytochrome-c oxidase-deficient muscle fibers of a patient with Kearns-Sayre syndrome. Proc Natl Acad Sci USA 86:9509-9513.

Mjaatvedt AE, Wong-Riley MTT (1988) Rclationship between synaptogenesis and cytochrome oxidase activity in Purkinje cells of the developing rat cerebellum. J Comp Neurol 277:155-182.
Mori M, Morita T, Ikeda F, Amaya Y, Tatibana M, Cohen PP (1981) Synthesis, intracellular transport, and processing of the precursors for mitochondrial ornithine transcarbamylase and carbamoyl-phosphate synthetase I in isolated hepatocytes. Proc Natl Acad Sci USA 78: 6056-6060.

Ojala D, Merkel C, Gelfand R, Attardi G (1980) The tRNA genes punctuate the reading of genetic information in human mitochondrial DNA. Cell 22:393-403.

Piko L, Taylor KD (1987) Amounts of mitochondrial DNA and abundance of some mitochondrial gene transcripts in early mouse embryos. Dev Biol 123:364-374.

Reid GA, Schatz G (1982) Import of proteins into mitochondria: extramitochondrial pools and post-translational import of mitochondrial protein precursors in vivo. J Biol Chem 257:13062-13067.

Reid GA, Yonetani T, Schatz G (1982) Import of proteins into mitochondria: import and maturation of the mitochondrial intermembrane space enzymes cytochrome $b_{2}$ and cytochrome $c$ peroxidase in intact yeast cells. J Biol Chem 257:13068-13074.

Rendon A, Masmoudi A (1985) Purification of non-synaptic and synaptic mitochondria and plasma membranes from rat brain by a rapid Percoll gradient procedure. J Neurosci Methods 14:41-51.

Rizzuto R, Nakase H, Darras B, Francke U, Fabrizi GM, Mengel T, Walsh F, Kadenbach B, DiMauro S, Schon EA (1989) A gene specifying subunit VIII of human cytochrome $c$ oxidase is localized to chromosome 11 and is expressed in both muscle and non-muscle tissues. J Biol Chem 264:10595-10600.

Sambrook J, Fritsch EF, Maniatis T (1989) Molecular cloning: a lahoratory manual, 2d ed. Cold Spring Harbor, NY: Cold Spring Harbor Press.

Shoubridge EA, Karpati G, Hastings KEM (1990) Deletion mutants are functionally dominant over wild-type mitochondrial genomes in skeletal muscle fiber segments in mitochondrial disease. Cell 62:4349.

Singer RH, Lawrence JB, Rashtchian RN (1987) Toward a rapid and sensitive in situ hybridization methodology using isotopic and nonisotopic probes. In: In situ hybridization: applications to neurobiology (Valentino KL, Eberwine JH, Barchas JD, eds), pp 71-96. New York: Oxford UP.

Steward O, Falk PM (1986) Protein-synthetic machinery at postsynaptic sites during synaptogenesis: a quantitative study of the association between polyribosomes and developing synapses. J Neurosci 6 : 412-423.

Vale RD (1987) Intracellular transport using microtubule-based motors. Annu Rev Ccll Biol 3:347-378.

Vale RD, Schnapp BJ, Reese TS, Sheetz MP (1985) Movement of organelles along filaments dissociated from the axoplasm of the squid giant axon. Cell 40:449-454.

Williams RS (1986) Mitochondrial gene expression in mammalian striated muscle. Evidence that variation in gene dosage is the major regulatory event. J Biol Chem 261:12390-12394.

Williams RS, Harlan W (1987) Effects of inhibition of mitochondrial protein synthesis in skeletal muscle. Am J Physiol 253:C866-C871.

Williams RS, Salmons S, Newsholme EA, Kaufman RE, Mellor J (1986) Regulation of nuclear and mitochondrial gene expression by contractile activity in skeletal muscle. J Biol Chem 261:376-380.

Williams RS, Garcia-Moll M, Mellor J, Salmons S, Harlan W (1987) Adaptation of skeletal muscle to increased contractile activity. Expression of nuclear genes encoding mitochondrial proteins. J Biol Chem 262:2764-2767.

Wong-Riley M (1979) Changes in the visual system of monocularly sutured or enucleated cats demonstrable with cytochrome oxidase histochemistry. Brain Res 171:11-28.

Wong-Riley M, Carroll EW (1984) Effect of impulse blockage on cytochrome oxidase activity in monkey visual system. Nature 307:262264.

Wong-Riley MTT (1989) Cytochrome oxidase: an endogenous metabolic marker for neuronal activity. Trends Neurosci 12:94-101.

Wong-Riley MTT, Welt C (1980) Histochemical changes in cytochrome oxidase of cortical barrels after vibrissal removal in neonatal and adult mice. Proc Natl Acad Sci USA 77:2333-2337.

Zeviani M, Nakagawa M, Herbert J, Lomax MI, Grossman LI, Sherbany AA, Miranda AF, DiMauro S, Schon EA (1987) Isolation of a cDNA clone encoding subunit IV of human cytochrome $c$ oxidase. Gene 55: 205-217. 